\title{
A BARBÁRIE MODERNA DO AGRONEGÓCIO VERSUS A AGRICULTURA CAMPONESA: IMPLICAÇÕES SOCIAIS E AMBIENTAIS $^{1}$
}

\author{
Rodrigo Simão Camacho \\ Doutorando em Geografia pela Universidade Estadual Paulista - Campus de Presidente Prudente \\ (São Paulo, Brasil) \\ E-mail: rogeo@ymail.com
}

Recibido: 16 de noviembre de 2011. Devuelto para revisión: 15 de diciembre de 2011.

Aceptado: 2 de enero de 2012

\begin{abstract}
RESUMO
O modelo agrário/agrícola nacional, dominado pelo capital nacional e internacional, baseado no latifúndio, na monocultura, no trabalho assalariado e na exportação, traz consequências negativas sociais e ambientais. Por isso, esse modelo representa, contraditoriamente, ao mesmo tempo, a Barbárie e a Modernidade. Neste sentido, a alternativa contrária a esse modelo está na construção de uma reforma agrária que permita a produção da agricultura camponesa e de todos os povos do campo de maneira plena, pois estes mantêm uma relação equilibrada com a natureza, produzem cultura no campo e cumprem um papel importante na produção de alimentos saudáveis para toda a população.
\end{abstract}

Palavras chave: Agronegócio, Agrocombustíveis, Preservação da Sociobiodiversidade, Latifúndio, Agricultura Camponesa.

\begin{abstract}
The agrarian/agriculturist model national, dominated for the national and international capital, based in the large estate, in the monocultivation, in the wage-earning work and the exportation, brings social and ambient negative consequences. Therefore, this model, contradictorily, represents, at the same time, the Barbarity and the Modernity. In this direction, the contrary alternative to this model is in the construction of an agrarian reform that peasant allows to the production of agriculture and all the peoples of the camp in full way, therefore these keeps a relation balanced with the nature, produces culture in the camp and fulfills to an important paper in the healthful food production for all the population.
\end{abstract}

Keywords: Agrobusiness, Agro-Fuel, Social and Ambient Diversity, Large Land Property, Peasant Agriculture.

\footnotetext{
${ }^{1}$ Este texto foi produzido tendo como base a nossa Dissertação de Mestrado em Geografia, concluída em Abril de 2008; o artigo final da disciplina: "Políticas Públicas, Agrocombustíveis e Soberania Alimentar" do Programa de Pós-graduação em Geografia da Unesp, escrito juntamente com Cubas e Gonçalves em 2010; e nossas reflexões iniciais de nossa tese de doutorado que está em construção.
} 


\section{RESUMEN}

El modelo agrario/agrícola nacional, dominado por el capital nacional e internacional, basado en el latifundio, en el monocultivo, en el trabajo asalariado y en la exportación, trae consecuencias negativas sociales y ambientales. Por lo tanto, este modelo representa, contradictorio, al mismo tiempo, la Barbaridad y la Modernidad. En esta dirección, la alternativa contraria a este modelo está en la construcción de una reforma agraria que permita a la producción de la agricultura campesina y a toda la gente del campo por completo, porque éstos mantienen una relación balanceada con la naturaleza, producen la cultura en el campo y satisfacen a un papel importante en la producción alimentaría saludable para toda la población.

Palabras clave: Agrobusiness, Agrocombustibles, Diversidad Social y Ambiental, Latifundio, Agricultura Campesina.

\section{INTRODUÇÃO}

Partindo do pressuposto de que a ciência não é neutra, devemos construir um debate profícuo na perspectiva teórica, política e ideológica a fim de revelar as diferenças acerca do modelo de sociedade que queremos construir. Dentro dessa lógica, existem duas realidades distintas no campo: uma é a realidade do agronegócio e a outra é a realidade dos povos do campo e da floresta. Sendo assim, pretendemos nesse nosso debate, desconstruir o discurso da ideologia neoliberal que busca colocar o agronegócio como sendo o modelo agropecuário viável para a nossa sociedade.

Existe a necessidade de refletirmos a respeito das conseqüências negativas existentes nas relações entre sociedade e natureza que estão subordinadas ao modo de produção capitalista. Pois, este modo de produção possui como essência a exploração do trabalho para a produção/reprodução, acúmulo e centralização do capital. Suas conseqüências podem ser visualizadas na degradação ambiental, no êxodo rural, na segregação socioespacial, na miserabilidade, na fome, na violência, no desemprego, etc. Logo, a única alternativa viável é a ruptura com as estruturas estabelecidas.

A relação entre monocultura e latifúndio tem formado uma combinação impactante social e ambientalmente. Tendo como principais cultivos a cana, a soja e o eucalipto, os agroecossistemas simplificados do agronegócio requerem a utilização cada vez maior de agroquímicos para combater pragas e garantir a produtividade, ocasionando grandes impactos a nossa sociobiodiversidade.

Destacamos a produção de impactos socioambientais e destruição da sociobiodiversidade por parte do agronegócio, porque além da destruição ambiental o agronegócio interrompe o processo humano de produção da cultura popular, pois des(re)territorializa os sujeitos produtores desta cultura no campo. Nos territórios onde o agronegócio se territorializou, são os territórios onde não existe a produção da cultura popular que a agri-cultura camponesa propicia, como as festas juninas que comemoram tradicionalmente as colheitas. Pois, o agri-negócio não produz cultura, somente capital, por isso que não existem festas populares onde o capital se territorializou. Logo, o agronegócio é Barbárie e Modernidade porque é predador da sociobiodiversidade.

Estamos no início de uma nova fase de produção de energia no Brasil, a dos agrocombustíveis, ou seja, a energia produzida a partir das plantas. Nesta perspectiva, o agronegócio no Brasil tem intensificado a monocultura dessas plantas. O Brasil, enquanto país tropical tem sido um dos 
maiores produtores mundiais, principalmente da cana. Essa combinação monoculturaagrocombustíveis-latifúndio, além da exclusão/expropriação dos povos do campo, e dos danos ambientais, tem sido um dos causadores do encarecimento de alimentos, atingindo as populações com menos recursos financeiros.

O agronegócio-latifundiário-exportador tem sido considerado como símbolo da modernidade no campo, mas esconde por trás da aparência moderna, a barbárie da exclusão social e expropriação dos povos do campo que sua concentração de terra e de renda provoca. Por isso, defendemos a agricultura camponesa e a dos povos tradicionais do campo por entender que estes possuem uma relação de equilíbrio com a natureza, fruto de sua prática da policultura orgânica, e porque estes entendem a produção de alimentos como requisito principal, pois visam a transformação da natureza, primordialmente, como forma de sobrevivência e não como forma mercadológica de produção de capital.

\section{O MODELO AGRÁRIO/AGRÍCOLA BRASILEIRO E SEUS IMAPACTOS SOCIAIS E AMBIENTAIS}

[...] transgênicos, produtos, orgânicos, vaca louca, Monsanto, Via Campesina, McDonald's, José Bové, gripe do frango, agronegócio, zapatistas, agroecologia, MST fazem parte de uma mesma tensão contraditória em que se debate o futuro da humanidade. (Porto-Gonçalves, 2004, p. 243).

Para Porto-Gonçalves, o atual modelo agrário/agrícola nacional, o agronegócio, está ancorado em dois pilares básicos: "[...] (1) no uso de um modo de produção de conhecimento próprio do capital que se traduz na supervalorização da ciência das técnicas ocidentais (que se querem universais); e (2) na expansão das terras cultivadas, sobretudo em regiões onde as terras são baratas". (2004, p. 224).

Segundo Fernandes (2009), o agronegócio é responsável pela expansão da conflitualidade, pois ampliou o controle sobre o território e as relações sociais, intensificando, assim, as injustiças sociais. Mas, diferentemente do latifúndio improdutivo, o agronegócio não significa apenas concentração fundiária, pois controla além da terra, as tecnologias de ponta. Assim, "O agronegócio é um novo tipo de latifúndio e ainda mais amplo, agora não concentra e domina apenas a terra, mas também a tecnologia de produção e as políticas de desenvolvimento. [...]". (p. 38).

A lógica desigual, contraditória e combinada do agronegócio é a mesma que rege as relações capitalistas de produção: quanto mais se produz, mais gera exploração do homem e da natureza, mais produz mais-valia, mais concentra/acumula/amplia o capital, e a consequencia desse processo é a ampliação das desigualdades sociais. Mas, a especificidade desse processo está no fato de que, atualmente, o domínio da ciência, técnica e informação em nível mundial (Santos, 2001), possibilitou ao capitalismo territorializado no campo produzir mais com menos tempo e espaço. Este fato aumentou o poder do agronegócio no Brasil e no mundo.

[...] O aumento da produtividade dilatou a sua contradição central: a desigualdade. A utilização de novas tecnologias tem possibilitado, cada vez mais, uma produção maior em áreas menores. Esse processo significou concentração de poder - conseqüentemente - de riqueza e de território. Essa expansão tem como ponto central o controle do conhecimento técnico, por meio de uma agricultura científica globalizada. (Fernandes, 2009, p. 39). 
Esse domínio tecnológico por parte do capital nunca será capaz de diminuir as desigualdades socioeconômicas, pois são geradas pela própria lógica destrutiva do capitalismo. O latifúndio improdutivo foi substituído, porém, o que ocorreu foi apenas uma inversão do motivo da exclusão social. Enquanto o latifúndio improdutivo excluía pela sua concentração de terra e nãoprodutividade, ao contrário, agora, é a super-produção do agronegócio que exclui. Nas palavras de Fernandes:

[...] O desenvolvimento do conhecimento que provocou as mudanças tecnológicas foi construído a partir da estrutura do modo capitalista de produção. De modo que houve o aperfeiçoamento do processo, mas não a solução dos problemas socioeconômicos e políticos: o latifúndio efetua a exclusão pela improdutividade, o agronegócio promove a exclusão pela intensa produtividade. [...]. (2009, p. 38, grifo nosso).

O discurso ideológico de produtividade e modernidade do agronegócio visa esconder a verdadeira essência estrutural que fundamenta a sua existência: a concentração de terra e renda e a exploração do ser humano e da natureza, exploração esta que chega ao limite do retorno ao tempo colonial com a ocorrência, muitas vezes, de trabalho análogo ao escravo. O que tivemos de mudança pode ser considerado apenas como sendo uma diminuição da importância do capitalrentista, característico dos países subdesenvolvidos. Dessa forma, independente do termo que podemos denominá-la: agricultura capitalista, agricultura patronal, agricultura empresarial, ou agronegócio, o que está na sua raiz, na sua essência, é a lógica destrutiva do capital.

O processo de construção da imagem do agronegócio oculta seu caráter concentrador, predador, expropriatório e excludente para dar relevância somente ao caráter produtivista, destacando o aumento da produção, da riqueza e das novas tecnologias. Todavia, a questão estrutural permanece. Do trabalho escravo à colheitadeira controlada por satélite, o processo de exploração e dominação está presente, a concentração da propriedade da terra se intensifica e a destruição do campesinato aumenta. [...]. (Fernandes, 2009, p. 38, grifo nosso).

Concordamos com Oliveira (2003) que o agronegócio é a contradição que pode ser sintetizada, concomitantemente, nos termos: "Barbárie e Modernidade", isso significa dizer que esse modelo agrário-agrícola nacional apresenta uma roupagem moderna de alta produtividade (que em se tratando de alimentos é mentira, pois quem mais produz é a pequena propriedade), com tecnologia avançada, produção de commodities, etc. Por outro lado, esconde, ideologicamente, suas raízes intrinsecamente ligadas ao modelo latifundiário colonial nacional de plantations e, logo, a sua exclusão social e degradação ambiental como continuidade. Daí a expressão "moderno-colonial" utilizada por Porto-Gonçalves para explicar as relações capitalistas ditas modernas nos países subdesenvolvidos. Como nas tradicionais "plantations" coloniais, o agronegócio baseia - se, ainda, na tríade: latifúndio, monocultura e exportação. Muda-se apenas a forma de exploração de trabalho, de escravo para assalariado, todavia, em muitos casos, este trabalho é, também, análogo ao escravo.

A estrutura desse modelo agrário-agrícola nacional é a aliança entre o capital nacional e o capital internacional: capitalistas proprietários de terra, o capital financeiro internacional, capital industrial agroquímico e o capital comercial. Vejamos a explicação de Porto-Gonçalves:

[...] esse modelo agrário-agrícola analisado, que se apresenta como o que há de mais moderno, sobretudo por sua capacidade produtiva, na verdade atualiza o 
que há de mais antigo e colonial em termos de padrão de poder ao estabelecer uma forte oligárquica entre: (1) as grandes corporações financeiras internacionais; (2) as grandes indústrias-laboratórios de adubos e de fertilizantes, de herbicidas e de sementes; (3) as grandes cadeias de comercialização ligadas aos supermercados e farmácias; e (4) os grandes latifúndios exportadores de grãos. Esses latifúndios produtivos são, mutatis mutandis, tão modernos como o foram as grandes fazendas e seus engenhos de produção da principal commodity dos séculos XVI e XVII: a cana-de-açúcar, no Brasil e nas Antilhas. À época não havia nada de mais moderno. A modernidade bem vale uma missa! (2004, p. 227).

Dessa forma, o agronegócio brasileiro é o capitalismo globalizado no campo em forma de latifúndio, fruto da internacionalização da economia brasileira. Houve assim, a união dos capitalistas latifundiários exportadores nacionais e as empresas transnacionais que controlam o mercado agrícola mundial, o resultado é o agronegócio. Nas palavras de Stedile:

Agronegócio é neoliberalismo da agricultura. Esse modelo neoliberal teve a sua amplitude também na agricultura. Selou-se uma aliança subordinada entre os grandes fazendeiros, os capitalistas, que se dedicam à exportação, com as empresas transnacionais que controlam o comércio agrícola internacional, as sementes, a produção de agrotóxicos e a agroindústria. O filhote desse matrimônio chamou-se agronegócio. [...]. (2006a, p.17).

Conforme nos explica Stedile (2006a), apesar de a palavra agronegócio significar qualquer operação comercial de produtos agrícolas, no Brasil, esse conceito ganhou uma nova significação, está relacionado com a implantação de um modelo de produção agrícola que, por sua vez, é fruto de uma aliança com o capital agropecuário internacional representado pela Associação Brasileira de Agribusiness. Seu fundador foi um grande produtor de cana, laranja e soja chamado Roberto Rodrigues.

O conceito de agronegócio, na língua portuguesa, que deriva da palavra agribusiness, foi cunhado em 1957 por Davis e Goldberg e significa um complexo de sistemas que integra todas as dimensões da economia capitalista: agricultura - indústria - comércio - finanças. Esses sistemas estão sob o controle das multinacionais.

A primeira formulação do conceito de agronegócio (agribusiness) é de Davis e Goldberg, 1957. Para os autores, o agronegócio é um complexo de sistemas que compreende agricultura, indústria, mercado e finanças. [...] Compreendemos que essa condição confere às transnacionais do agronegócio um poder extraordinário que possibilita a manipulação dos processos em todos os sistemas do complexo. (Fernandes, 2008a, p.165, grifo do autor).

Nesse conjunto complexo de sistemas globalizados temos dez empresas transnacionais que controlam todo o mercado do setor de agronegócio. Segundo Stedile (2006a, p.17): “[...] Monsanto, Bunge, Cargil, ADM, Basf, Bayer, Sygenta, Novartis, Nestlé e Danone, controlam praticamente toda a produção agrícola, de agrotóxicos, de sementes transgênicas e o comércio agrícola de exportação". Corroborando nesta análise Gorender afirma que existe uma participação política do Estado em benefício dessas empresas transnacionais. É, pois, “[...] uma política conjugada com interesse da indústria de equipamentos e de insumos agrícolas e com indústria transformadora das matérias-primas agrícolas, setores nos quais predominam amplamente as grandes multinacionais imperialistas. [...]". (2002, p.37). 
Neste sentido, temos uma realidade brasileira que é marcada pela desigualdade e exploração. E, por sua vez, de acordo com Oliveira, temos que entender essas questões de maneira plena, num contexto de internacionalização da economia do Brasil num mundo capitalista globalizado. Isto quer dizer que, hoje, os grandes grupos econômicos - nacionais e, sobretudo, internacionais comandam a exploração de nossos recursos naturais visando à exportação. Esta lógica, por sua vez, é justificada pelos governantes e pelas elites como sendo necessária para o pagamento da dívida externa que, entretanto, é impagável. Ou seja, o trabalhador brasileiro vende sua força de trabalho para que as nações desenvolvidas se apropriem de nossos recursos naturais. Dito de outra maneira:

A sociedade se move, se agita. Os grandes grupos econômicos vão implantando seus grandes projetos de exploração/expropriação das riquezas naturais do país. E em nome do "exportar é o que importa", a riqueza produzida no Brasil não tem conseguido pagar a impagável dívida externa que estes mesmos trabalhadores não fizeram.

O lugar do Brasil no contexto do capitalismo monopolista se redefiniu, redefinindo o lugar internacional do trabalho dos trabalhadores brasileiros. O país produz para as nações avançadas consumirem. E objetivando produzir para exportar, o país endividou-se e foi endividado. A lógica da dívida não é e é, ao mesmo tempo, nacional. A economia brasileira internacionalizou-se, mundializou-se no seio do capitalismo mundial. (Oliveira, 1994, p.136).

Devido ao processo de internacionalização da economia temos uma maior atenção e apoio ao agronegócio, se tornando a prioridade econômica e política por ser, segundo o discurso ideológico da nossa elite, modernizador do campo brasileiro. Entretanto, o que essa aparência esconde é a concentração de terra e renda que, por sua vez, produz a exclusão social no campo brasileiro. Confirmando essa análise, Balduíno (2004, p.23) afirma que o agronegócio é “[...] portador de divisas, modernizador, aglutinador de uma elite rica, porém, ao mesmo tempo, concentrador de renda e de terra e gerador de pobreza na população do campo". Em outras palavras o agronegócio é ao mesmo tempo: "Barbárie e Modernidade" (Oliveira, p.2003).

Com essas características descritas, os impactos sociais causados por este modelo de produção agrícola, são notáveis na sociedade brasileira. Tendo em vista que o aumento da concentração fundiária, característica inerente ao modelo de produção do agronegócio, expulsa os camponeses de suas terras, causando o êxodo rural. Corroborando nesta análise, Stedile afirma que: "[...] a concentração da propriedade da terra continuou aumentando. Eles acumularam nestes últimos anos mais de 30 milhões de hectares, somente nas fazendas acima de 1.000 hectares [...]". (2006a, p.17).

Do outro lado, também, a mecanização da produção, outra característica intrínseca a esse modelo, retira as possibilidades de emprego no campo. Por isso, segundo Stedile: "[...] no ano passado, 300.000 assalariados rurais perderam o emprego no campo e foram para a cidade [...]". (2006a, p.17). Também, ao contrário do que se pensa, o uso das sementes transgênicas não está diretamente associada ao aumento da produtividade, mas sim, a diminuição de custos com mãode-obra devido à possibilidade de não precisar combater as pragas e as facilidades de semeadura. O resultado disso é a produção de uma "agricultura sem agricultores", pois se necessita de menos empregos no campo, elevando-se o êxodo rural e todas as conseqüências negativas deste processo. Gerando a diminuição da população do campo que, consequentemente, acarreta vários problemas urbanos como: a exclusão social na cidade, o desemprego, a segregação socioespacial, a violência urbana etc. Assim, os transgênicos, além de serem uma forma degradante ambientalmente de produção, porque gera a erosão genética, também acarretam o desemprego no campo, como explica Porto-Gonçalves: 
[...] Trata-se, portanto, de uma técnica que acentua a tendência a uma agricultura sem agricultores, agravando problemas num momento em que o novo padrão de poder proporcionado pelas novas tecnologias também não emprega tanta gente nas cidades e suas periferias, como o fazia à época da desruralização européia e estadunidense. (2004, p. 227, grifo nosso).

Como podemos visualizar na Figura 1, contraditoriamente, houve um aumento das terras utilizadas no Brasil, mas proporcionalmente, houve uma diminuição das pessoas ocupadas nos estabelecimentos agropecuários, sobretudo, a partir de 1996.

Figura 1. Trabalhadores Rurais X Áreas de Lavoura no Brasil (1920-2006).

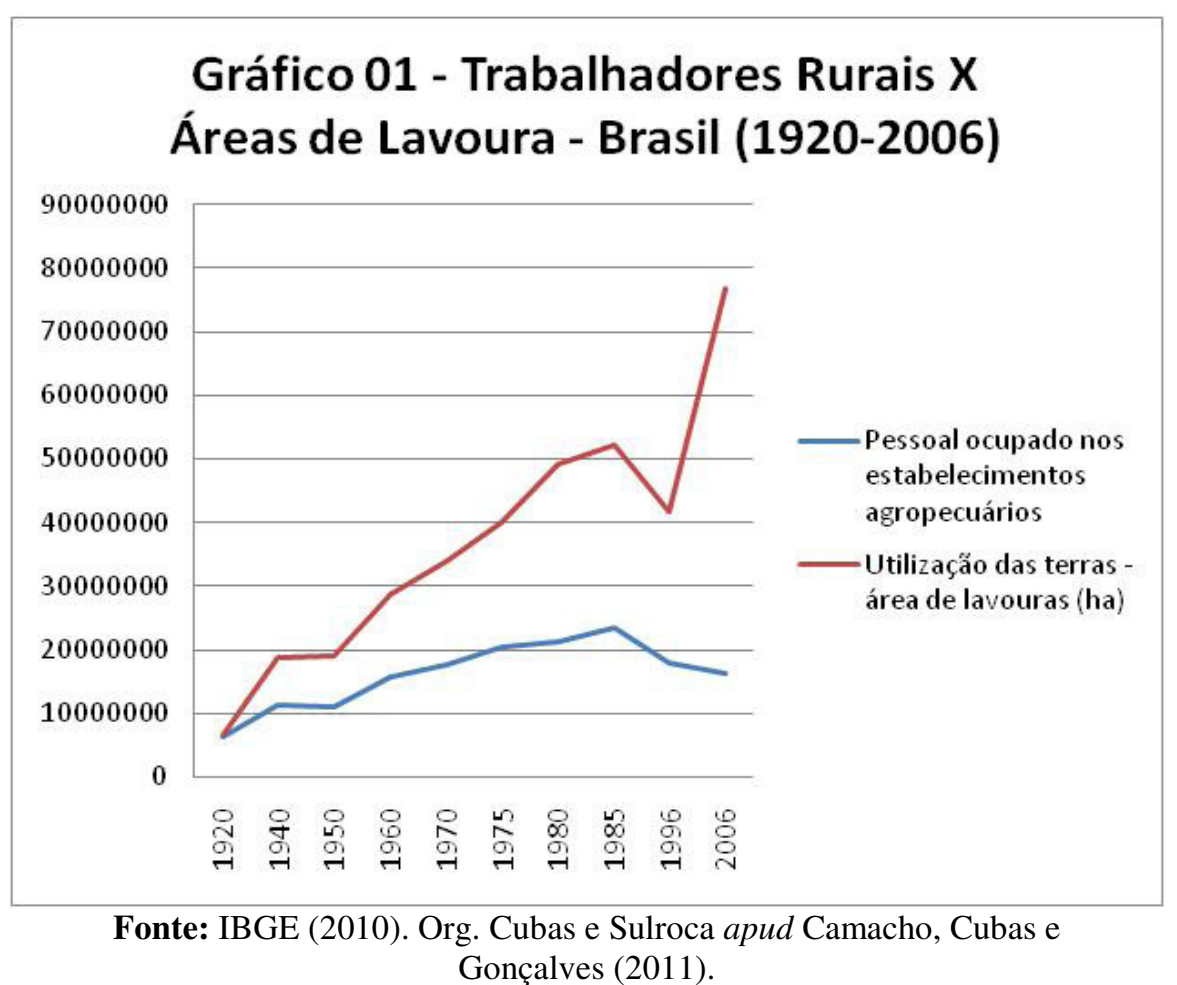

A monocultura, outra característica do agronegócio, fragiliza a biodiversidade, colaborando no aumento de pragas, devido à homogeneização do ecossistema e, sobretudo, colocando em risco a segurança alimentar, já que se produz para exportar estimulando produções que nem sequer se destinam a alimentação. E, por último, temos o uso de agrotóxicos que polui o solo e a água destruindo a nossa biodiversidade. Dessa forma, a combinação destrutiva do agronegócio se dá pela relação entre as seguintes características: grandes extensões de terras, baixos salários pagos aos trabalhadores, monocultura e uso de agrotóxicos. Nas palavras de Stedile (2006a, p.17):

[...] Essa é a formula de competitividade de nossos sábios empresários agrícolas: apropriação de grandes extensões de terra para aumentar a escala combinada com os mais baixos salários da agricultura capitalista do mundo. Suas técnicas agridem o meio ambiente. O uso intensivo de agrotóxicos aplicados irresponsavelmente, combinado com monocultura, destrói a biodiversidade e compromete os recursos naturais para as gerações futuras.

Os agroecossistemas produzidos pelo agronegócio comprometem a biodiversidade, pois a monocultura simplifica ao extremo as relações naturais existentes, necessitando de uma grande 
quantidade de insumos externos, como adubos e agrotóxicos para que a produção possa acontecer. Pois, a dependência de alguns poucos cultivadores, torna esses agroecossistemas vulneráveis a pragas e às variações climáticas. Essa relação se torna ainda mais delicada quando verificamos que esses agroecossistemas estão sendo implantados no Brasil e no restante dos países tropicais tendo como base uma racionalidade científica européia, cujo clima é temperado e não o tropical. Por isso, necessitaríamos de outra racionalidade técnica-científica para produção em países tropicais, pois nesses lugares os impactos se tornam mais violentos que nos países de clima temperado que tem uma menor quantidade de energia solar envolvida no processo e onde a diversidade biológica é menos intensa. É necessário sabermos que a implantação dos agroecossistemas simplificados não responde da mesma forma em biomas distintos. Todavia, nossa ciência eurocêntrica tenta, ideologicamente, homogeneizar esses ecossistemas por interesses de exploração da nossa biodiversidade, reduzindo a complexidade desses sistemas naturais tropicais. Relação esta que se estabelece desde a época colonial. Como explica PortoGonçalves:

São graves as consequiências que se avizinham com a expansão para novas áreas de uma lógica mercantil que reduz a complexidade dos ecossistemas e de múltiplas culturas a agroecossistemas simplificados com os monocultivos de soja, milho, girassol, algodão, eucalipto e pinnus. Atente-se ainda, para o fato de os diferentes biomas do planeta não respondem da mesma forma às ações que sobre eles se fazem. A complexidade da dinâmica de matéria e energia das regiões tropicais, sabidamente menos conhecida pela ciência ocidental, com frequiência vê todo um sistema técnico-agrícola pensando a partir de uma ciência natural desenvolvida a partir de dinâmicas mais simplificadas das regiões frias e temperadas ser arrogantemente transplantando, com conseqüências socioambientais danosas. (2004, p.230).

Devido à fragilidade desses agroecossistemas se faz necessário o uso cada vez maior de insumos agroquímicos. É notável como vem aumentando a quantidade do uso desses insumos ao longo do tempo. Esse aumento é alvo de críticas por parte de entidades preocupadas com o bem-estar das pessoas e do meio-ambiente no campo.

A expansão exponencial do uso de adubos e fertilizantes, herbicidas, pesticidas, e fungicidas vem sendo há décadas objeto de intensas críticas de ambientalistas de órgãos ligadas à saúde e de sindicatos de trabalhadores, sobretudo rurais. Nos últimos cinqüenta anos, enquanto a produção de grãos aumentou três vezes, o uso de fertilizantes foi multiplicado simplesmente catorze vezes, segundo dados da FAO. Assim, a relação entre produção de grãos e uso de fertilizantes caiu de 42 toneladas para 13 toneladas de grãos por cada tonelada de fertilizante usada entre 1950 e 2000. Uma queda significativa! (Porto-Gonçalves, 2004, p.225).

Esses insumos agroquímicos não ofendem somente a natureza, mas atingem diretamente a saúde dos moradores e/ou trabalhadores do campo. Neste sentido, Porto-Gonçalves nos relata que até o desfolhante químico conhecido como "agente laranja" foi usado no preparo da terra para a plantação de grãos na região norte conhecida como "Bico do Papagaio". Esse produto foi usado pelos EUA na guerra do Vietnã e até hoje seus efeitos estão presentes na população do país.

Ainda recentemente, em novembro de 2002, pudemos constatar no preparo da terra para o cultivo de grãos na região do Bico do Papagaio, entre o Maranhão e o Tocantins, lançamento, por avião, do desfolhante químico conhecido como agente laranja, de triste memória pelo seu amplo uso na guerra do Vietnã. Assim, aqueles que trabalham na agricultura sofrem o impacto direto do uso 
desses derivados da agroquímica, com sérios danos à sua saúde, conforme acusa uma ampla literatura médica e científica. (2004, p.225).

O MST, a Via Campesina Brasil, junto com outras entidades, lançaram a campanha em 2011 intitulada: Agrotóxico Mata: campanha permanente contra os agrotóxicos e pela vida. A fim de alertar a população acerca dos perigos dos agrotóxicos para a saúde humana e para o meio ambiente, bem como, dos abusos de que o agronegócio faz do mesmo. Somos o país que mais usa agrotóxicos no mundo, sendo que cada brasileiro consome cerca de 5,2 litros de venenos por ano. Vejamos o que diz a campanha:

Cada brasileiro consome 5,2 litros de venenos por ano. O Brasil é o maior consumidor de agrotóxico do mundo desde 2009. Mais de um bilhão de litros de venenos foram jogados nas lavouras, de acordo com dados oficiais. Os agrotóxicos contaminam a produção dos alimentos que comemos e a água (dos rios, lagos, chuvas e os lençóis freáticos) que bebemos! Mas os venenos não estão só no nosso prato. Todos, o ambiente, os animais e nós, seres humanos, estamos ameaçados! Os agrotóxicos causam uma série de doenças muito sérias, que atacam os trabalhadores rurais, comunidades rurais e toda a população, que consome alimentos com substâncias tóxicas e adquire muitas doenças.

Outra questão de suma importância com relação ao agronegócio, diz respeito à violência no campo, ou seja, existe uma relação entre a territorialização do capital no campo e o aumento da violência, inclusive com assassinatos de lideranças dos movimentos sociais camponeses, o que confirma a barbárie do agronegócio e sua natureza moderna-colonial:

[...] Dados recentes divulgados pela CPT dão conta de que os Estados brasileiros por onde se expande o agronegócio são aqueles em que é maior o número de lideranças de trabalhadores rurais assassinadas e de famílias despejadas. [...] o Mato Grosso, governado pelo maior produtor de soja do mundo, Blairo Maggi, somente no ano 2003 o equivale a 6,2\% da população rural foi simplesmente despejada de suas terras ou das terras que reivindicam. [...]. Nem no período colonial se conseguiu tal façanha. (Porto-Gonçalves, 2004, p.224).

Dessa forma, entendemos que essa combinação de latifúndio, exploração intensa da mão-deobra, monocultura, agrotóxicos, mecanização, transgênicos e produção de commodities, mostrase insustentável. Por isso, nossa opção teórica - política - ideológica é pela agricultura camponesa.

\section{A AGRICULTURA DOS POVOS DO CAMPO: PELA SOBERANIA ALIMENTAR E PELA PRESERVAÇÃO DA SOCIOBIODIVERSIDADE}

Se planta o arroz aqui

Se planta o milho acolá

Um jeito de produzir

Pra gente se alimentar

Primeiro cantar do galo

Já se levanta da cama

E o camponês se mistura

A terra que tanto ama Amar o campo ao fazer a plantação Não envenenar o campo é purificar o pão Amar a terra e nela botar semente 
A gente cultiva ela, e ela cultiva a gente A gente cultiva ela, e ela cultiva a gente Choro virou alegria

A fome virou fartura

E na festa da colheita

Viola e noite de lua

Mutirão é a harmonia

Com cheiro de natureza

O sol se esconde na serra

$E$ a gente acende a fogueira

Quando se envenena a terra

A chuva leva pro rio

Nossa poesia chora

Se a vida tá por um fio

E ela é pra ser vivida

Com sonho arte e beleza

Caminhos alternativos

E alimentação na mesa

Zé Pinto

A reforma agrária é a opção contrária a esse modelo dominante. Ela pode ser entendida como sendo "o conjunto de medidas que visem promover melhor a distribuição da terra, mediante modificações no regime de sua posse e uso, a fim de atender aos princípios de justiça social e ao aumento de produtividade". (Almeida, 2004, p.1). Assim, se faz necessário discuti-la numa perspectiva socialista, de embate com indústria nacional e multinacional, pois, somente assim, o pequeno produtor pode conseguir ganhar o suficiente para viver com dignidade no campo. Logo, "[...] É impossível um produtor de leite ganhar mais pelo seu leite sem que a Nestlé, o leite Glória, percam [...]". (Stedile, 2002, p.314). Por isso, entendemos que a luta pela reforma agrária deve se tratar de uma luta contra o capital. Ou seja, deve ir além de um modelo conservador de simples distribuição de terra. Pois, estas empresas do agronegócio subordinam a renda do campesinato lhes condenando a miséria. Reproduzindo seu capital por meio da renda extraída do campesinato. É o processo de produção de capital por relações não-capitalistas, fruto do desenvolvimento desigual e contraditório do capital. Que dá origem a monopolização do território pelo capital monopolista que possibilita a reprodução do campesinato, mas de forma precária (Oliveira, 2004).

É por esta razão que a luta pela terra não se encerra em si, devendo ser entendida, sobretudo como luta contra o capital. Isso retira o sentido de uma reforma agrária distributivista, pois a renda encontra-se subjugada pelo capital, impedindo o trabalhador familiar de libertar-se do circulo de miserabilidade que lhes é imposto. (Almeida; Paulino, 2000, p.122).

O florescimento da agricultura camponesa favorecerá a economia do país como um todo, para todos. Porém, sempre houve a opção, por parte do Estado capitalista brasileiro, de beneficiar ao agronegócio latifundiário, priorizando os produtos destinados a exportação, ao invés, da produção de alimentos para a população (Gorender, 2002). Assim, temos que entender que a dominação do agronegócio no Brasil traz uma problemática para os estudos de geografia agrária, visto que existe um antagonismo hoje no campo entre o agronegócio e a reforma agrária, isto é, o "agronegócio latifundiário, predador, destruidor, não cabe ao lado de uma reforma agrária". (Casaldáliga, 2005, p.11). Esta dominação do agronegócio no Brasil tem como apoiadores os veículos de comunicação de massa. Em uma reportagem o jornal "O Estado de São Paulo" diz que os assentamentos e, conseqüentemente, a reforma agrária são os principais responsáveis pelo 
desmatamento da Amazônia. Distorcendo, dessa forma, a verdade sobre os fatos, pois os verdadeiros responsáveis pela destruição ambiental da Floresta Amazônica são os latifúndios do agronegócio, as empresas de madeira, e o latifúndio grilado. Logo, o que se mascara, nos veículos de comunicação dominantes, é a realidade e a luta de classes em torno de projetos distintos de agricultura.

[...] a reforma agrária é responsável por apenas 15 por cento do desmatamento e, em sete anos, os assentamentos destruíram apenas 10 por cento da mata remanescente. A matéria não diz que os outros 85 por cento do desmatamento foram causados pelos latifundiários, pelos grileiros e pelas madeireiras, ilegais que atuam na Amazônia. Já imaginaram o Estadão admitir que a reforma agrária é uma boa!? (Souza, 2006, p.9).

É no sentido do contraponto a ordem vigente que Stedile (2006a) apresenta uma concepção alternativa acerca da questão agrária, proposta pelos movimentos sociais do campo, as pastorais das igrejas, os ambientalistas, as 45 entidades que compõem o Fórum Nacional de Reforma Agrária, e as mais diferentes representações de trabalhadores rurais do povo que vive no meio rural. A alternativa que essas organizações defendem é a que busca um equilíbrio entre homem e a natureza. Onde a transformação da natureza tenha o objetivo principal de satisfazer as necessidades básicas do ser humano, ao contrário, do atual processo globalitário ${ }^{2}$ de mercantilização da natureza que acarreta, conseqüentemente, um desequilíbrio ambiental. Também, entendem que o campo pertence aos seus povos e comunidades que foram, por sua vez, excluídas no processo de globalização capitalista, do qual faz parte o agronegócio latifundiário. Neste sentido, está entre as prioridades alternativas da produção no campo, a fim de assegurar a sociobiodiversidade, a delimitação do tamanho das propriedades, a policultura e a produção de alimentos sem transgênicos e agrotóxicos. Portanto, de forma geral, essas são as características de produção da agricultura camponesa e dos povos tradicionais do campo. Com essa forma de produção no campo, acreditamos que seja possível construir outra realidade onde não se degrade o meio-ambiente preservando-o para as futuras gerações. Entendemos também, que a partir desta perspectiva é possível garantir condições de vida digna no campo para seus habitantes, desterritorializando o capital e territorializando os camponeses. Evitando, dessa maneira, que os detentores do agronegócio explorem os camponeses sem-terra e produzam a expulsão e proletarização do campesinato, gerando a miséria e a exclusão social.

Defendemos utilizar as terras e os recursos naturais de nossa sociedade de outra forma. Defendemos organizar em pequenas e médias unidades de produção (poderiam ser até 1.000 hectares, mas precisam ter um limite), defendemos a policultura como forma de aproveitar melhor o potencial do solo, do clima e a preservação da biodiversidade. Queremos priorizar a produção de alimentos, e alimentos saudáveis, sem agrotóxicos. Queremos uma agricultura que absorva mão-de-obra, gere trabalho. Garanta renda a todos os que trabalham no meio rural e não apenas aos grandes proprietários, que em geral moram nas capitais. Queremos estimular o uso de técnicas agrícolas que respeitem o meio ambiente e o preservem para as gerações futuras. Queremos a adoção e multiplicação de sementes convencionais, já adaptadas à nossa natureza, e contra os transgênicos, que são apenas uma forma de as transnacionais nos explorarem com royalties. (Stedile, 2006a, p.17).

Nesta perspectiva, os povos do campo e da floresta, camponeses, quilombolas, indígenas, seringueiros, pescadores etc., continuam produzindo sua subsistência numa relação equilibrada

\footnotetext{
${ }^{2}$ Globalização autoritária/totalitária, que impõe a todos a mesma forma de viver (Santos, 2001).
} 
com a natureza de maneira diametralmente oposta ao agronegócio. Ou seja, neste período de globalização esses povos chamam "[...] a atenção para o fato de suas práticas culturais específicas serem aquelas que mais se coadunam com os interesses da humanidade e da ecologia do planeta e, por isso, devem ser respeitadas enquanto tais". (Porto-Gonçalves, 2004, p.208).

No entanto, o capitalismo segue sua lógica perversa no campo, tendo como características essenciais: o consumismo desenfreado e a exploração descomedida da natureza. Exploração da natureza combinada com a exploração das pessoas, pois este processo gera mais-valia, permitindo a acumulação/reprodução do capital. É, por isso, que esse processo de desenvolvimento capitalista no campo é responsável pela exclusão e marginalização dos povos, além da destruição da biodiversidade, colocando em risco toda a humanidade. Logo, o que temos é a destruição da sociobiodiversidade, visto que toda a humanidade necessita dessa biodiversidade para continuar vivendo:

O custo dessa exploração da natureza e das pessoas junto ao consumismo desenfreado foi pago pelo sacrifício de milhões de trabalhadores pobres, camponeses, indígenas, pastores, pescadores, e outras pessoas pobres da sociedade, que entregam suas vidas a cada dia. E pela agressão permanente da natureza que foi e continua sendo sistematicamente devastada. Sua integridade e a diversidade de formas de vida, que são o sustento da biodiversidade, estão ameaçadas. E, se a natureza de nosso planeta está ameaçada, está ameaçada a própria vida humana, que depende dela. [...] (Stedile et al., 2006b, p.40).

Essa destruição biológica e cultural e, portanto, da sociobiodiversidade, efetuada pela territorialização do capital no campo e seu agroecossistema simplificado tem como uma de suas causas à homogeneização/simplificação dos ecossistemas que, por isso, necessitam de uma grande quantidade de insumos industrializados para manter sua reprodução. $\mathrm{O}$ emprego desses insumos tem como conseqüência a poluição dos rios e dos solos, causando a morte de peixes e comprometendo a reprodução das comunidades ribeirinhas que tem na pesca uma atividade principal ou complementar de sua subsistência (Porto-Gonçalves, 2004). Entendemos que a sobrevivência dos povos do campo e a reprodução das suas relações de trabalho com a terra são, portanto, condição essencial para a manutenção da existência da nossa biodiversidade, tendo em vista que esses povos possuem uma relação com a natureza de respeito e preservação. Pois, as vêem como parte inerente de sua sobrevivência e, ao contrário da burguesia, não enxergam a natureza enquanto uma fonte de exploração para o lucro e, sobretudo, não a transforma em mercadoria. Podemos afirmar que durante, cerca de milênios de anos, esses povos, como os índios, mantiveram uma relação equilibrada com a natureza. Contudo, essa relação foi rompida com os modelos de produção eurocêntricos, desde o período colonial, e, mais recente, com as formas estadunidenses de produção agrícola para exportação, como a revolução verde. Por isso, é necessário que seja reconhecido o direito dos povos do campo ao seu território, para que estes povos ajudem a humanidade a prosseguir com um maior equilíbrio socioambiental, por meio do cultivo de alimentos sem agrotóxicos, com sementes naturais (crioulas e nativas) e não transgeneticamente modificadas (Stedile et al. 2006b).

Devido a grande incidência atual de alimentos transgeneticamente modificados se faz necessário refletirmos a respeito da importância de preservarmos e de reproduzirmos essas sementes crioulas, pois a extinção dessas sementes acarretará, fatalmente, a extinção de espécies milenares necessárias à sobrevivência humana e preservadas durante várias gerações pelos povos do campo. Por isso, com relação aos OTMs (organismos transgeneticamente modificados), PortoGonçalves nos faz um alerta sobre a diferença destes para os OGMs (organismos geneticamente modificados). Pois, todas as espécies se modificam geneticamente ao longo do tempo e por 
intervenção dos diversos povos em sua relação com a natureza. Os produtos inserem-se na cultura desses povos, ou seja, ocorre a humanização do processo da produção de alimentos. Do outro lado, os transgênicos são produzidos artificialmente em laboratórios. Vejamos essa explicação em suas palavras:

[...] a expressão OGM - organismo geneticamente modificado - é genérica e imprecisa. Rigorosamente falando, toda a evolução das espécies se dá por modificação genética, que, assim, é um fenômeno natural. As invenções de espécie cultivadas - trigo, milho, arroz, mandioca, pupunha são invenções culturais, cultivares - e se fizeram enquanto modificação genética desenvolvida por diferentes povos e suas culturas em íntima relação com a natureza. São, assim, um produto cultural e natural. Já os OTMs são, criações laboratoriais e, portanto, não foram tecidos e experimentados em convivência com a natureza. (2004, p.234).

É imprescindível pensarmos a respeito da contaminação genética que está ocorrendo, pois as culturas transgênicas misturam-se facilmente às produções orgânicas por meio dos ventos, das chuvas, dos animais etc., contaminando-as. Hoje é muito difícil conseguirmos separar os alimentos orgânicos dos transgeneticamente modificados, devido a essa poluição genética. $\mathrm{O}$ que pode acarretar a extinção de diversas espécies, além do que não sabemos certamente ainda quais são seus efeitos para o ser humano.

Entretanto, a questão da possibilidade de separar ou não os organismos transgeneticamente modificados da dinâmica do fluxo de matéria e energia natural e culturalmente existente se coloca como de extrema relevância de imediato, aqui e agora, independentemente dos seus efeitos na natureza, inclusive para a saúde humana [...]. (Porto-Gonçalves, 2004, p.236).

Estamos observando no mundo inteiro a extinção de diversas espécies em nome da uniformização comercial. É a chamada erosão genética que extingue espécies. E os resultados negativos dessa uniformização da agricultura mundial podem ser confirmados pelas perdas de colheitas em diversas épocas porque suas culturas ficaram mais vulneráveis as pragas:

90\% de nossa alimentação procede de apenas quinze espécie de plantas e de oito espécie de animais. [...]. As novas espécie de cultivares substituem as nativas, uniformizando a agricultura e destruindo a diversidade genética. Só na Indonésia formam extintas 1500 variedades de arroz nos últimos quinze anos. À medida que cresce a uniformidade, aumenta a vulnerabilidade. A perda da colheita da batata na Irlanda em 1846, a do milho nos Estados Unidos em 1970 ou a do trigo na Rússia em 1972 são exemplos dos perigos da erosão genética e mostram a necessidade de preservar variedades nativas das plantas, inclusive para criar novas variedades melhoradas e resistentes às pragas. A engenharia genética levará à perda de milhares de variedades de plantas, ao se cultivar só algumas poucas com alta produtividade [...]. (Santamarta apud PortoGonçalves, 2004, p.209).

O monopólio das sementes por parte das grandes corporações multi/transnacionais tendem a aumentar a insegurança alimentar, pois a principal necessidade humana, alimentação, perseguida em todo o nosso processo de hominização, passa a fazer parte agora de um ciclo econômico mundial, cujo principal objetivo é satisfazer as necessidades de lucro dessas empresas. Essa relação apesar de atingir de forma mais intensa os países subdesenvolvidos, atingem também os países desenvolvidos. A “[...] agricultura inglesa, por exemplo, importa cada vez mais. De cada 
cinco frutos vendidos, quatro vem do exterior e não dos pomares domésticos, antes tão numerosos do campo inglês. [...]”. (Porto-Gonçalves, 2004, p.210).

Nessa direção, uma questão de relevante importância para refletirmos é a soberania alimentar, ou seja, a necessidade que um povo tem de produzir seus próprios alimentos, de maneira suficiente para toda a população. "A soberania alimentar é entendida como um princípio que define o direito e até o dever que cada povo tem de produzir os alimentos de que necessita para sua sobrevivência [...]". (Stedile, 2007, p.42). Essa questão se mostra fundamental, principalmente na atualidade em que começa a ficar mais rentável plantar os agrocombustíveis, ao invés de alimentos. Essa inversão de prioridades ocorre porque a produção agrícola para o capitalismo e, conseqüentemente, para o agronegócio não passa de mais uma mercadoria, onde o alimento também se torna mercadoria, cuja produção depende do retorno financeiro que esse "negócio" dará. Porém, a alimentação é a primeira necessidade humana, e, logo, é a primeira função do trabalho na transformação da natureza (Engels, 1977), por isso deve ser a prioridade a ser produzida independente do retorno financeiro. Portanto, é a agricultura camponesa que deve ser a prioridade das políticas públicas e não o agronegócio. Corroborando com nossa análise, Stedile afirma: "o alimento é um direito de todos os seres humanos e não mera mercadoria da qual busca extrair lucros [...]". (2007, p.42). Logo, a produção agrícola camponesa baseada na policultura, é essencial para manter a soberania alimentar.

Podemos sintetizar as marcantes diferenças entre a agricultura camponesa e o agronegócio por meio da oposição existente entre o campo diversificado e ambientalmente saudável onde predomina a agricultura camponesa e o campo vazio e ambientalmente em risco onde predomina o agronegócio. Todavia, não podemos generalizar as observações acerca da agricultura camponesa e, conseqüentemente, seu antagonismo com relação ao agronegócio tendo como base apenas a dicotomia de paisagens, tratando essa problemática a partir de uma análise idealista e simplista, pois a própria lógica de mercado impõe a produção de escala ao camponês, até como requisito para que o produto chegue ao mercado. Por isso, não é raro ver camponeses ocupados com uma única atividade comercial. Este fato confirma a necessidade de luta contra o capital. Essa monopolização do território pelo capital (Oliveira, 1999; 2004), pode ser entendida, também, como a territorialidade do capital em território camponês (Fernandes, 2009), ou seja, é a influência do agronegócio no território camponês que faz com que ele tenha que produzir para vender seu produto para agroindústrias capitalistas tendo parte de sua renda apropriada pelo capital.

Assim, de maneira geral, com o objetivo de marcar as diferenças, entre essas duas formas de produzir no campo, temos de um lado a agricultura camponesa que constrói um campo de inclusão social e de preservação da sociobiodiversidade. Devido à numerosa população existente no campo, este é um território de vida e produção material e simbólica de seus habitantes. Inclusive possibilitando a construção da Educação do Campo, dos movimentos sociais, das festas e dos cultos camponeses. Do outro lado, antagonicamente, o agronegócio com a produção da monocultura em latifúndios para a exportação, tecnificada e que, com o uso abusivo de agrotóxicos e de transgênicos, coloca em risco a soberania alimentar, destrói a sociobiodiversidade, expropria o camponês gerando a miséria e a exclusão social. Transformam o espaço rural em uma mercadoria útil para o "negócio", ou seja, no agronegócio o meio rural não passa de um espaço de negócio, onde a vida não se reproduz nesse espaço, nele o único ganhador é o capitalista latifundiário, em detrimento do restante da sociedade. Dessa forma, vejamos o quadro abaixo que nos mostra esses antagonismos existentes no campo, descritos por Fernandes e Molina (2004, p.85): 


\section{CAMPO DO AGRONEGÓCIO}

MONOCULTURA - COMMODITIES

PAISAGEM HOMOGÊNEA E SIMPLIFICADA

PRODUÇÃO PARA EXPORTAÇÃO (PREFERENCIALMENTE)

CULTIVO E CRIAÇÃO ONDE PREDOMINA AS ESPÉCIES EXÓTICAS

EROSÃO GENÉTICA

TECNOLOGIA DE EXCEÇÃO COM ELEVADOS NÍVEL DE INSUMOS EXTERNOS

COMPETITIVIDADE E ELIMINAÇÃO DE EMPREGOS

CONCENTRAÇ̃̃o DE RIQUEZAS, AUMENTO DA MISÉRIA E DA INJUSTIÇA SOCIAL.

ÊXODO RURAL E PERIFERIAS URBANAS INCHADAS

CAMPO COM POUCA GENTE

CAMPO DO TRABALHO ASSALARIADO (EM DECRÉSCIMO)

PARADIGMA DA EDUCAÇÃO RURAL

PERDA DA DIVERSIDADE CULTURAL

\author{
CAMPO DA AGRICULTURA \\ CAMPONESA \\ POLICULTURA - USO MÚLTIPLO DOS \\ RECURSOS NATURAIS \\ PAISAGEM HETEROGÊNEA E COMPLEXA \\ PRODUÇÃo PARA O MERCADO INTERNO E \\ PARA EXPORTAÇÃO \\ CULTIVO E CRIAÇÃO ONDE PREDOMINA AS \\ ESPÉCIES NATIVAS E DA CULTURA LOCAL \\ CONSERVAÇÃO E ENRIQUECIMENTO DA \\ DIVERSIDADE BIOLÓGICA \\ TECNOLOGIA APROPRIADA, APOIADA NO \\ SABER LOCAL COM BASE NO USO DA \\ PRODUTIVIDADE BIOLÓGICA PRIMÁRIA DA \\ NATUREZA. \\ TrabalHo Familiar E GERAÇão DE \\ EMPREGOS \\ DEMOCRATIZAÇÃO DAS RIQUEZAS - \\ DESENVOLVIMENTO LOCAL
}

PERMANÊNCIA, RESISTÊNCIA NA TERRA E MIGRAÇ̃̃O URBANO - RURAL.

CAMPO COM MUITA GENTE, COM CASA, COM ESCOLA...

CAMPO DO TRABALHO FAMILIAR E DA RECIPROCIDADE

PARADIGMAS DA EDUCAÇÃO DO CAMPO

RIQUEZA CULTURAL DIVERSIFICADA FESTAS, DANÇAS, POESIAS - MUSICA EXEMPLO: O MATO GROSSO É O MAIOR PRODUTOR BRASILEIRO DE MILHO E NÃO COMEMORA AS FESTAS JUNINAS. JÁ NO NORDESTE...

AGRI-CULTURA

\section{AGRO-NEGÓCIO}

Fernandes explica que a agricultura capitalista ou agronegócio e o campesinato constroem territórios distintos, com paisagens distintas e antagônicas que pressupõe o conflito constante entre os mesmos. De um lado, o agronegócio organiza seu território apenas a partir da lógica econômica da mercadoria, constituída pelas relações sociais de produção capitalista, por isso predomina a paisagem homogênea da monocultura, com poucas pessoas e com pouca sociobiodiversidade. Antagonicamente a esse modelo, os camponeses organizam seus territórios a partir de relações sociais não-capitalistas para a reprodução material e simbólica da vida em sua totalidade, por isso seus territórios perpassam todas as dimensões da realidade, entre elas, a cultura, a educação, a alimentação, o lazer etc., são povoados e de paisagens heterogêneas, contemplando a sociobiodiversidade e os agroecossistemas complexos.

[...] enquanto o agronegócio organiza seu território para produção de mercadorias, o grupo de camponeses organiza seu território, primeiro, para sua existência, precisando desenvolver todas as dimensões da vida. Esta diferença se expressa na paisagem e pode ser observada nas distintas formas de organização dos dois territórios. A paisagem do território do agronegócio é homogêneo, enquanto a paisagem do território camponês é heterogêneo. A composição uniforme e geométrica da monocultura se caracteriza pela pouca presença de pessoas no território, porque sua área está ocupada por mercadoria, que predomina na paisagem. A mercadoria é a expressão do território do agronegócio. A diversidade dos elementos que compõem a paisagem do território camponês é caracterizada pela grande presença de pessoas no território, porque é neste e deste espaço que constroem suas existências, 
produzindo alimentos. Homens, mulheres, jovens, meninos e meninas, moradias, produção de mercadorias, culturas e infra-estrutura social, entre outros, são os componentes da paisagem dos territórios camponeses. (Fernandes, 2008b, p. 284).

Com relação a cultura no campo, para Porto-Gonçalves, a cultura "[...] está associada à distribuição da riqueza no sentido forte da palavra e não necessariamente ao negócio! Eis o contraste entre a agricultura e o agrinegócio!" (2004, p.245, grifo do autor). Quanto à diferenciação da produção cultural entre a agricultura camponesa e o agronegócio, PortoGonçalves (2004) faz uma comparação sobre as diferenças de relações que ocorrem nos territórios onde predomina a agricultura camponesa e nos territórios do agronegócio. Como sabemos a agricultura é produzida por pessoas que, por sua vez, produzem cultura a partir de suas relações socioespaciais e históricas vivenciadas nesse processo. Todavia, no agronegócio a produção agrícola não está relacionada à produção cultural, tendo em vista que não é uma produção que envolve os sujeitos territorializados no processo, pois a importância do agronegócio, como diz o próprio nome, é o "negócio", ou seja, o lucro. Este fato faz desses territórios, onde o capital se territorializou, o local da expropriação camponesa, de poucos trabalhadores assalariados e de muitas máquinas. Porto-Gonçalves, traz um exemplo concreto para demonstrarmos essa dicotomia que é o seguinte: faz parte da tradição popular brasileira no mês de junho a comemoração da festa junina que está relacionada ao fim das colheitas. Neste sentido, o autor compara o que ocorre na mesma data no Centro-Oeste brasileiro - território do Blairo Maggi, maior produtor de soja do mundo, e maior região produtora de milho do Brasil com o Nordeste e Minas Gerais, onde se predomina a agricultura camponesa:

[...] Talvez a própria mudança de nome, de agricultura para agronegócio, como gostam de chamar o setor, os seus próprios protagonistas, indique onde está o problema. No Brasil, durante o mês de junho ocorrem festas religiosas geralmente associadas à colheita, sobretudo a do milho. A expansão do agronegócio pelo Centro-Oeste, ocupando suas chapadas, tem feito dessa região a maior produtora de milho do Brasil. Entretanto, milhares de sertanejos no Nordeste e em Minas Gerais festejam efusivamente São João e São Pedro, sejam Caruaru, Campina Grande, Sobral, Crato, Feira de Santana, Jequié, Montes Claros, entre tantos arraiais onde se come canjica, bolo de milho, curau, quindim, pamonha, milho cozido - que se misturam na alegria de tantas barraquinhas, tantos empregos, namoros, danças e distribuição de renda - e, ao que se sabe, nenhuma dessas festas está associada a colheitas feitas com grandes máquinas e com tão pouco empregos no Centro-Oeste brasileiro, onde vêm sendo jogadas todas as fichas de um modelo de desenvolvimento no mais tradicional estilo moderno. [...]. (2004, p.245, grifo do autor).

Essa descrição emocionante feita por Porto-Gonçalves nos confirma a ambigüidade inerente ao agronegócio já afirmada por Oliveira (2003): "Barbárie e Modernidade”. Dessa forma, com a territorialização do capital no campo, ou seja, com o processo de expansão do agronegócio, "[...] não só se perde diversidade biológica, mas também diversidade cultural e múltiplas formas de propriedade distintas da propriedade privada [...]". (Porto-Gonçalves, 2004, p.224). Outro exemplo que podemos resgatar é o da substituição das festas populares tradicionais do interior do Estado de São Paulo pelos agrishows, festa-espetáculo, para qual uma empresa de eventos contrata artistas do showbusiness, principalmente em Ribeirão Preto; e em Barretos, com a festa do Peão Boiadeiro. Onde se importa uma cultura estadunidense em oposição à cultura popular paulista. Além da destruição cultural, este fato expõe a territorialização do capital, principalmente pelas usinas destiladoras de álcool. O capital retira do camponês a possibilidade que no passado tinha de ser sujeito e não espectador das festas paulistas. 
[...] Ali, muitos espectadores se farão presentes aplaudindo o que se passa no palco, não necessariamente tão ativos como montando barraquinhas, fazendo bandeirinhas, preparando seus doces e salgados ou dançando uma quadrilha. Com certeza em Ribeirão Preto e Barretos sempre há espaço para montar uma barraca de cachorro-quente e para vender cerveja, por aqueles que têm que reinventar a vida nas circunstâncias possíveis. (Porto-Gonçalves, 2004, p.244-245).

\section{A MONOCULTURA DE (AGRO) COMBUSTÍVEIS DO AGRONEGÓCIO VERSUS A "ALIMERGIA" CAMPONESA}

Mudanças muito marcantes com relação à ciência, a técnica e a informação fazem com que nosso período histórico seja diferente dos demais (Santos, 2001). No entanto, uma das diferenças marcantes dessa nova etapa de desenvolvimento do capitalismo globalizado no Brasil, está relacionada à produção de combustíveis vegetais ou (agro) combustíveis, por ser considerada energia limpa e renovável. Anteriormente, no Brasil e no mundo, tínhamos como elemento energético, quase exclusivo, os combustíveis fósseis, como o petróleo e o carvão mineral. Vesentini afirma que: “[...] na década de 1960 o petróleo contribuía com mais de $60 \%$ da oferta mundial de energia [...] e, atualmente ele contribui com cerca de $20 \%$ [...]". (1995, p.9). Isto está ocorrendo porque outras fontes de energia, em especial, as oriundas da biotecnologia, estão sendo usadas. Todavia, a quantidade dos combustíveis fósseis utilizados ainda hoje é muito grande, contando com $80 \%$ do total de participação na energia mundial. Contra $13 \%$ de participação de fontes renováveis. O quadro geral hoje de participação da energia mundial é de: “35\% do Petróleo, 25\% do Carbón vegetal, 21\% do Gás, $10 \%$ da Biomasa y resíduos, 6\% da Nuclear, $2 \%$ da Hidroeléctrica, $1 \%$ de Otras fuentes renovables" (AIE ${ }^{3}$ apud FAO, 2008). No entanto, essa porcentagem varia muito entre os países, sendo que nos países subdesenvolvidos a biomassa pode contribuir em até $90 \%$ do consumo total de energia.

As principais causas apontadas para que a Organização para a Cooperação e o Desenvolvimento Econômico (OCDE) incentive a produção dos agrocombustíveis são: garantir a segurança energética, reduzir a emissão dos gases que provocam o efeito estufa/mudança climática e impulsionar o desenvolvimento rural. Entretanto, apesar de todas essas questões continuarem sendo relevantes no mundo globalizado atual, a participação dos agrocombustíveis para atingir essas finalidades deve passar por uma discussão acerca dos modelos de desenvolvimento que temos baseados na lógica do capital globalizado.

[...] El principal motor impulsor de las políticas nacionales de la $\mathrm{OCDE}^{4}$ han sido los objetivos de seguridad energética y mitigación del cambio climático mediante la reducción de las emisiones de gases de efecto invernadero, en conjunción con El deseo de apoyar la agricultura y promover el desarrollo rural. Estas preocupaciones no están disminuyendo; por el contrario, el cambio climático y la seguridad de la energía en el futuro adquieren cada vez mayor relevancia en las políticas internacionales. Sin embargo, el papel de los biocombustibles en la solución de estos problemas, comprendidas las políticas adecuadas que deberán aplicarse, están siendo objeto de un examen más riguroso. [...]. (FAO, 2008, p. 21).

\footnotetext{
${ }^{3}$ AIE - Agencia Internacional de Energía.

${ }^{4}$ Organización para la Cooperación y el Desarrollo Económicos
} 
A energia conseguida a partir das plantas, ou seja, os combustíveis vegetais ou (agro) combustíveis são produzidos a partir da fotossíntese das plantas. Assim, nos explica o físico Vidal (2007, p.36): "são combustíveis vegetais, renováveis e limpos do ponto de vista ambiental, de natureza química, que substituem os combustíveis derivados do petróleo e podem ser obtidos a partir da energia solar por meio da fotossíntese das plantas. [...]". Ainda, segundo Vidal, os combustíveis vegetais são: “[...] a) álcool etílico, obtido por fermentação dos açúcares ou amidos; b) os óleos vegetais e a celulose, e seus inúmeros derivados. [...]”. (2007, p.36). Esses combustíveis são considerados renováveis porque tem origem na radiação solar. E eles não produzem o efeito estufa porque o balanço entre a quantidade de dióxido de carbono retirado do ar, pelas plantas utilizadas na sua produção, e a quantidade liberada na sua queima acaba resultando em um total negativo, ou seja, “[...] o $\mathrm{CO}_{2}$ retirado da atmosfera para a formação dos hidratos de carbono e lipídeos das plantas e o $\mathrm{CO}_{2}$ resultante da queima dos combustíveis vegetais derivados - etanol, óleos vegetais e celulose, e seus derivados”. (Vidal, 2007, p.36).

A partir de algumas dessas premissas e do discurso de engendrar desenvolvimento, empregos, renda etc. é que se implanta no Brasil: Programa Nacional de Produção e Uso do Biodiesel $(P N P B)$. Este programa tem o objetivo de Implantar o biodiesel na Matriz Energética Brasileira de combustíveis líquidos (PNPB, 2010). Segundo o documento este é um Progrma do Governo Federal, “[...] que objetiva a implementação de forma sustentável, tanto técnica, como economicamente, a produção e uso do Biodiesel, com enfoque na inclusão social e no desenvolvimento regional, via geração de emprego e renda”. (PNPB, 2010, p. 1). É parte integrante desse programa a "Lei $\mathrm{n}^{\mathbf{0}}$ 11.097, de 13 de janeiro de 2005, [que] estabelece a obrigatoriedade da adição de um percentual mínimo de biodiesel ao óleo diesel comercializado ao consumidor, em qualquer parte do território nacional. [...]". (PNPB, 2010, p. 1). Essa proposta objetiva diminuir a quantidade de diesel importado constituindo uma economia para o país.

Hoje, 10\% do diesel consumido no Brasil são importados. Este combustível, utilizado principalmente no transporte de passageiros e de cargas, é o mais utilizado no país, com comercialização anual da ordem de 38,2 bilhões de litros, o que corresponde a $57,7 \%$ do consumo nacional de combustíveis veiculares. O biodiesel permite a economia de divisas com a importação de petróleo e óleo diesel, trata-se de uma vantagem estratégica ao reduzir a dependência das importações de petróleo [...]. (PNPB, 2010, p. 7).

Como forma de incentivo para que os camponeses plantem os (agro) biocombustíveis, o governo possibilitará o acesso ao "[...] crédito aos pequenos agricultores por meio do Pronaf, "[...] assim como acesso à assistência técnica, fornecida pelas próprias empresas detentoras do Selo Combustível Social, com apoio do MDA por meio de parceiros públicos e privados. [...]". (PNPB, 2010, p. 3, grifo nosso).

A principal planta utilizada como forma de produção de combustível no Brasil é a cana-deaçúcar, transformada em álcool ou etanol, tendo em vista que a cana-de-açúcar é uma planta típica dos países tropicais, pois necessita de calor e água em abundância para se reproduzir. Neste sentido, o Brasil, enquanto maior país tropical do mundo, tende a dominar a produção mundial do produto. Neste contexto, muda-se, assim, a lógica das relações comerciais internacionais vigentes até então, pois, os países desenvolvidos, Europa e EUA, não possuem o clima tropical necessário para o desenvolvimento desse produto, obrigando-os a vir comercializar esse produto com os países subdesenvolvidos tropicais. Corroborando nesta análise, o sociólogo Vasconcelos afirma que: "A questão é física, geográfica, evolvendo a 
incidência de sol, de quantidade de calor e de água doce [...] nenhum gênio ianque, japa ou tesdesco será capaz de inventar uma tecnologia, digamos, um computador prodígio, que consiga transferir o sol de Belém do Pará para Wall Street”. (2007, p.34).

Acompanhando essa lógica, podemos dizer que com a detenção dos mananciais energéticos nos trópicos, o imperialismo estadunidense revigora-se, uma vez que a energia é essencial para o desenvolvimento da sociedade moderna nos países dominantes. Portanto, muda-se a configuração geopolítica do século XXI, implantando-se o que poderíamos denominar de uma nova forma de colonialismo dos países dominantes sobre os países tropicais (Vasconcelos, 2007, p.34). Os combustíveis fósseis, principalmente o petróleo, a máquina a vapor, e o carvão mineral, foram utilizados, até então, pela humanidade, e, sobretudo, pelos países dominantes, "[...] países colonialistas e imperialistas que tomaram a dianteira da história nos últimos trezentos anos, a Inglaterra e os Estados Unidos [...]" (Vasconcelos, 2007, p.34), proporcionando a eles esse patamar de desenvolvimento tecnológico que estão hoje. Por isso, a energia é um fator primordial de desenvolvimento da sociedade capitalista após a revolução industrial. Entretanto, esses combustíveis utilizados até hoje, além de serem finitos e não-renováveis, se mostraram, também, extremamente ofensivos à natureza (Vasconcelos, 2007), inclusive, na concepção de alguns pesquisadores (porque não é um consenso entre os pesquisadores que estudam o clima), sendo responsáveis pela aceleração do aquecimento global.

Neste sentido, o imperialismo dos países desenvolvidos fica evidente quando constatamos que empresas trans/multinacionais estão interessadas em produzir o etanol em nosso território e, conseqüentemente, explorar nossa mão-de-obra e destruir nossa biodiversidade. Essas empresas têm como prática produtiva o uso descomedido de agrotóxicos e a produção em monocultura que visa à exportação a fim de atender as necessidades de consumo de seus países imperialistadominantes de origem. Países estes, da Europa, além do Japão e, sobretudo, o EUA. Sendo assim, inúmeras multinacionais estão interessadas em instalar suas usinas em nosso território. Entre os interessados nesse negócio, está o já "bilhardário" Bill Gates, como nos diz Vasconcelos:

[...] o saqueio do território brasileiro já está montado e planejado. General Motors, Nascar, GM, Indy. As multinacionais estão excitadíssimas em tacar mão no etanol dos trópicos, assim como o nada bobo Bill Gates, com sua Ethanol Pacific, na Califórnia, está a fim de comprar as terras de Mato Grosso e Goiás. [...] Japonês, Holandês, multinacionais, estão a fim de erguer usinas de álcool em Mato Grosso do Sul e Paraná. (2007, p.34).

Podemos ter a certeza de que tanto à burguesia dos países imperialistas, assim como a burguesia nacional, não estão preocupadas em preservar a nossa sociobiodiversidade, pois o que interessa para estes é o lucro a qualquer custo. Para eles, os fins justificam os meios. Por isso, é nosso dever zelar pela sociobiodiversidade presente em nosso território, pois não serão eles que irão fazer isso por nós. Visto que para eles, os trabalhadores e a natureza são mercadorias a serem compradas e usufruídas para aumentar os lucros e garantir a vitória na concorrência do mercado internacional. O Sol e a Água deixam de ser elementos naturais e, passam a ser agora, objetos de apropriação. Transformam-se, então, na única coisa importante para a burguesia internacional e nacional em nosso território. E a população, dessa maneira, se torna elemento residual. Nas palavras de Vasconcelos:

Os gringos estão interessados apenas no sol e na água dos trópicos, mas não estão nem aí para a existência do povo brasileiro. A dádiva geográfica do sol e da água será um infortúnio coletivo. Não haverá necessidade nem de explorar a mão-de-obra local. É o genocídio. Mate o brasileiro, preserve a floresta. 
Chegaremos logo nessa loucura. Os interesses das multinacionais cobiçam a floresta. Dane-se o território povoado por gente brasileira. Um território sem população, com um Estado alquebrado e Forças Armadas desprovidas de defesas. [...]. (2007, p.34-35).

Questão importante a ser discutida, diz respeito aos trabalhadores assalariados do campo, os "bóias-frias", empregados principalmente no plantio e corte da cana-de-açúcar. Estes são, em sua maioria, migrantes, principalmente do Nordeste para o Centro-Sul, são, aproximadamente, 20 mil bóias-frias por ano que migram. Esta migração tem levado ao aumento do número de favelas, de assassinatos, de tráfico de drogas, de comércio de crianças e de adolescentes destinados à prostituição (Betto, 2007). No trabalho do corte da cana foram registrados, inclusive, casos de morte por exaustão. Foram registrados, também, incidência de trabalho escravo e semiescravo, além da degradação ambiental que sempre acompanhou a produção da monocultura para a exportação. Os trabalhadores, na maioria das vezes, são submetidos a uma jornada fatigante que, quando não leva a morte, causam sérios problemas de saúde. Poucos têm os seus direitos trabalhistas regulamentados:

A produção de cana no Brasil é historicamente conhecida pela superexploração do trabalho, destruição do meio ambiente e apropriação indevida de recursos públicos. As usinas se caracterizam pela concentração de terras para o monocultivo voltado à exportação. Utilizam em geral mão-deobra migrante, os bóias-frias, sem direitos trabalhistas regulamentados. Os trabalhadores são (mal) remunerados pela quantidade de cana cortada, e não pelo número de horas trabalhadas. $\mathrm{E}$ ainda assim não têm controle sobre a pesagem do que produzem. Alguns chegam a cortar, obrigados, 15 toneladas por dia. Tamanho esforço causa sérios problemas de saúde, como câimbras e tendinites, afetando a coluna e os pés. A maioria das contratações se dá por intermediários (trabalho terceirizado) ou "gatos", arregimentadores de trabalho escravo ou semi-escravo. Após 1850, um escravo costumava trabalhar no corte de cana por 15 a 20 anos. Hoje, o trabalho excessivo reduziu este tempo médio para 12 anos $^{6}$. (Betto, 2007, não paginado).

Outra problemática que se coloca com relação aos agrocombustíveis é o do encarecimento dos alimentos $^{7}$. O aumento dos preços dos alimentos, a pesar de não ter como único motivo a substituição das culturas alimentares pelas culturas energéticas, suscitou um amplo debate acerca de a soberania alimentar. Tendo em vista que "[...] Los precios de los alimentos han aumentado rápidamente, provocando protestas en muchos países y generando graves preocupaciones sobre la seguridad alimentaria de las personas más vulnerables del mundo". (FAO, 2008, p. 18). A respeito desse assunto, Frei Betto traz alguns dados importantes da OCDE e da FAO:

\footnotetext{
5 Bóia Fria - Trabalhador rural que presta serviços eventuais e/ou por safra. Chamada assim por comer fria a comida que leva de casa. (Almeida, 2004, p. 2).

${ }^{6}$ Devido a todos esses aspectos negativos envolvendo a produção dos (agro/bio) combustíveis, Frei Betto (2007), prefere os nomear de (necro) combustíveis, ao invés de (bio) combustíveis, pois os mesmos estão mais ligados as causas de morte e do que de vida.

${ }^{7}$ No entanto, temos que considerar que, além dos agrocombustíveis, existem inúmeros fatores que levaram ao aumento do preço dos alimentos, sendo assim, o aumento da produção dos agrocombustíveis é apenas um deles. Dentre esses fatores podemos sintetizá-los, segundo Stedile (2008), em uma causa estrutural e outra causa conjuntural. Estrutural: o modelo predador e o comércio oligopólico que concentra o controle da produção e a propriedade das terras, o resultado é que algumas empresas controlam todo o comércio mundial de alimentos e impõem os preços que querem. O fator conjuntural é a crise do capitalismo nos Estados Unidos e na Europa.
} 
Estudo da OCDE e da FAO, divulgado a 4 de julho, indica que "os biocombustíveis terão forte impacto na agricultura entre 2007 e 2016." Os preços agrícolas ficarão acima da média dos últimos dez anos. Os grãos deverão custar de 20 a $50 \%$ mais. No Brasil, a população pagou três vezes mais pelos alimentos no primeiro semestre deste ano, se comparado ao mesmo período de 2006. (2007, não paginado).

Segundo Stedile (2011) os preços dos alimentos subiram em média 13\% nos últimos 12 meses. Alguns produtos chegaram a $13 \%$. Este fato atinge toda a população diretamente na compra de alimentos e indiretamente com o aumento da inflação. Os preços dos alimentos sobem porque estão sob o controle oligopolizado de poucas empresas. Não temos um aumento nos custos da produção, o que aumentou foi o lucro das empresas. $\mathrm{O}$ aumento do preço dos alimentos não é uma característica apenas do Brasil, mas é um fenômeno que vem causando transtornos tanto nos países desenvolvidos quanto nos países subdesenvolvidos. Vejamos o que está acontecendo no mundo:

Os preços dos alimentos já sobem em ritmo acelerado na Europa, na China, na Índia e nos EUA. A agflação - a inflação dos produtos agrícolas - deve chegar, este ano, a 4\% nos EUA, comparada ao aumento de 2,5\% em 2006. Lá, como o milho está quase todo destinado à produção de etanol, o preço do frango subiu $30 \%$ nos últimos doze meses. E o leite deve subir $14 \%$ este ano. Na Europa, a manteiga já está $40 \%$ mais cara. No México, houve mobilização popular contra o aumento de $60 \%$ no preço das tortillas, feitas de milho. (Betto, 2007, não paginado).

Vejamos na Figura 2 o aumento da produção de culturas destinadas a exportação - commodities - em detrimento das culturas alimentares no Brasil, tendo como recorte temporal de comparação 2009 e 2010:

Figura 2. $\mathrm{O}$ aumento da produção de commodities no Brasil.

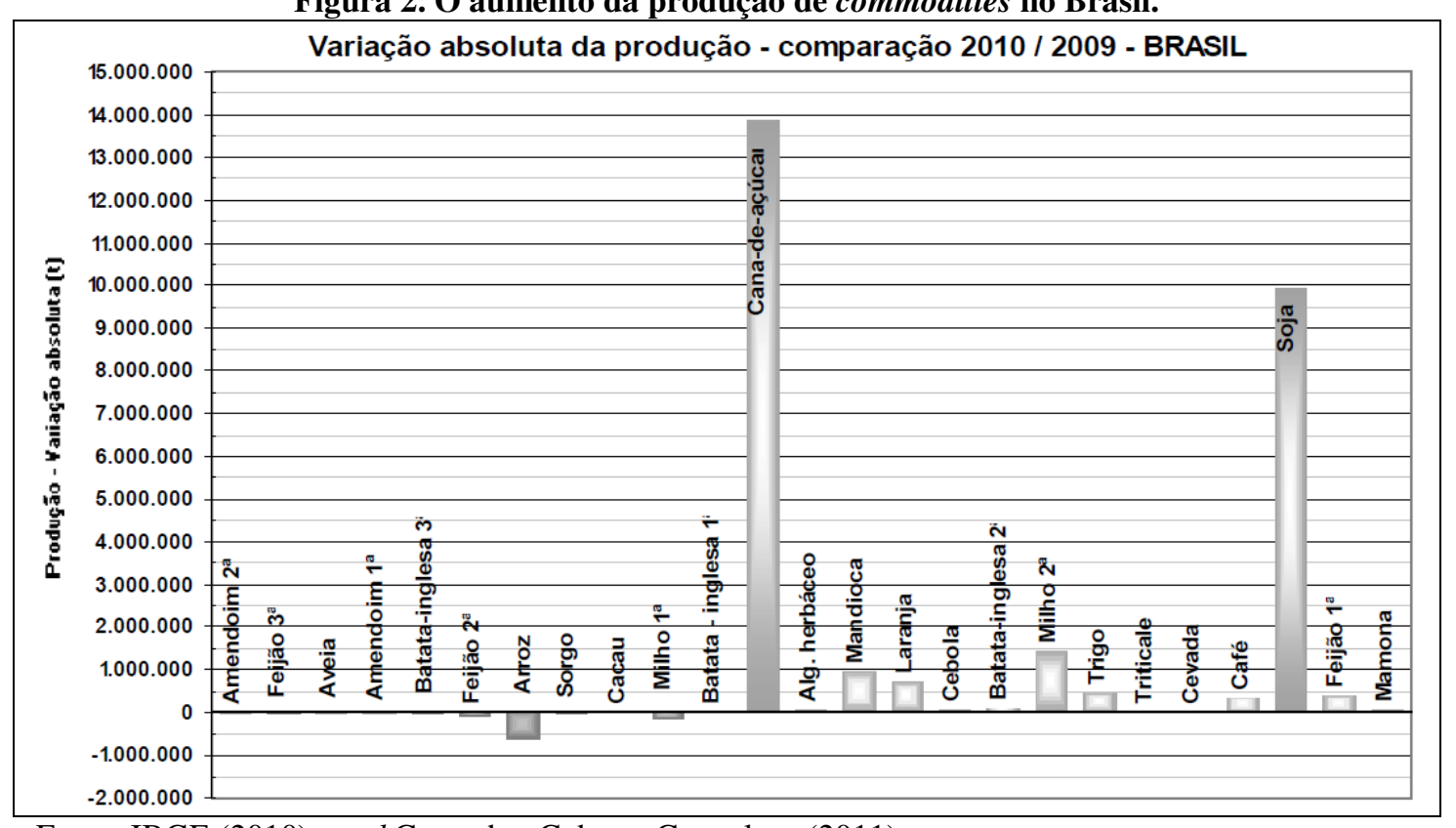

Fonte: IBGE (2010) apud Camacho, Cubas e Gonçalves (2011).

Podemos notar que a Cana-de-açúcar (14 milhões de toneladas) e a Soja (10 milhões de toneladas), que são produtos destinados a exportação (no caso da cana, a produção do álcool é 
que é exportada), tem destaque no cenário nacional. Estas duas culturas/commodities cresceram em detrimento da produção de cultuas alimentares, como o Arroz, o Feijão, o Milho e a Mandioca que estão numa amplitude de variação absoluta negativa para positiva com no máximo de 2 milhões de toneladas, no caso do Milho, por exemplo. Isso reforça nossas reflexões sobre o modelo agrário/agrícola nacional: a expansão dos territórios do agronegócio, para as comoditties, e a redução da produção de alimentos da agricultura camponesa, visto que a mesma é colocada em segundo plano pelas políticas públicas do Brasil (Camacho; Cubas; Gonçalves, 2011).

O que está em jogo nessa oposição entre produção de alimentos e de agrocombustíveis é a valorização da produção de energias, ditas como sustentáveis, em oposição à produção de alimentos que é a necessidade básica do ser humano. Tendo em vista que o acesso aos alimentos é uma possibilidade plena das classes dominantes, o que eles precisam, na verdade, é de uma forma alternativa de alimentar seus automóveis potentes após o fim da era do petróleo, ou como forma de se declarar como sendo a favor de energias ecologicamente corretas. Por isso, a fome e a desnutrição têm uma importância menor do que a energia que alimenta os carros. Os objetos passam a ter mais valor que o ser humano no modo de produção capitalista, é o "ter" sobre o "ser", é o "valor de troca" que se sobressai ao "valor de uso".

Vamos alimentar carros e desnutrir pessoas. Há 800 milhões de veículos automotores no mundo. O mesmo número de pessoas sobrevive em desnutrição crônica. O que inquieta é que nenhum dos governos entusiasmados com os agrocombustíveis questiona o modelo de transporte individual, como se os lucros da indústria automobilística fossem intocáveis. (Betto, 2007, não paginado).

Dessa forma, Frei Betto aponta que uma das opções seria investir em fontes de energia alternativa: hidráulica, solar, biogás, eólica etc. e, assim, priorizar a alimentação da população mais pobre. Em suas palavras: "O governo brasileiro precisa livrar-se da sua síndrome de Colosso (a famosa tela de Goya). [...] E cuidar de alimentar os sofridos famintos, antes de enriquecer os 'heróicos' usineiros ${ }^{8 "}$. (2007, não paginado). Nesta perspectiva, segundo a FAO: “[...] Cada vez se cuestiona más la eficacia en función de los costos de la reducción de las emisiones mediante el desarrollo de los biocombustibles [...]”. (2008, p. 22).

Vamos conhecer alguns posicionamentos dos movimentos camponeses com relação à produção de energia. A Via Campesina - Brasil faz uma intensa crítica à produção dos agrocombustíveis. Alertando sobre a problemática da substituição da produção de alimentos por energia e afirmando que o modelo estabelecido de produção de agrocombustíveis ao invés de trazer benefícios ao meio ambiente, por meio da substituição dos combustíveis fósseis pelo biodiesel, vai acabar aumentando os impactos. "A produção industrial de agrocombustíveis vai aumentar o aquecimento global, em vez de proporcionar a redução. A monocultura de palma, soja, milho ou cana de açúcar vai contribuir na deflorestação e na destruição da biodiversidade". (Via Campesina, 2010, p.1). A Via Campesina não acredita na solução da crise socioambiental por meio da tecnologia, mas sim, por meio da organização dos sujeitos sociais em busca de outro modelo de produção, distribuição, circulação e consumo.

A Via Campesina acredita que as soluções para a atual crise têm que surgir de atores sociais organizados, que estão desenvolvendo modelos de produção,

\footnotetext{
${ }^{88}$ Frase proferida pelo, então, presidente da república Luiz Inácio Lula da Silva.
} 
comércio e consumo baseados na justiça, na solidariedade e em comunidades saudáveis. Nenhuma solução tecnológica vai resolver o desastre do meio ambiente ou social. Somente uma mudança radical na forma como produzimos, comercializamos e consumimos pode dar terras para comunidades rurais e urbanas saudáveis. A agricultura sustentável em pequena escala, um trabalho intensivo e de pouco consumo de energia pode contribuir para o resfriamento da terra. (Via Campesina, 2010, p.2).

Apesar da opinião contrária da Via Campesina com relação à produção dos agrocombustíveis, temos algumas experiências alternativas realizadas por alguns movimentos camponeses de produção de energia de maneira sustentável. Vamos mostrar aqui uma experiência que conhecemos no sul do Brasil, que está sendo desenvolvida pelo Movimento dos Pequenos Agricultores (MPA), nos municípios de Frederico Westphalen e Caiçara, os dois localizados no Estado de Rio Grande Sul. Podemos dizer, com base nesta experiência, que as experiências camponesas de produção, conjugando energia e alimentos, têm diferenças significativas com relação ao modelo agrário/agrícola de produção do agronegócio, tendo em vista que o princípio primordial é a associação inseparável entre a produção de culturas alimentares e de culturas para produção de energia dentro de seus territórios. Outras diferenças marcantes são as seguintes: não há exploração do trabalho, a forma de produção se baseia no trabalho familiar, sendo assim, podemos concebê-la como uma forma de produção que não se baseia nas relações sociais de produção tipicamente capitalistas; toda a produção é feita em pequenas propriedades; não há monocultura de cana ou de eucalipto, ou seja, existe uma relação da plantação da canade-açúcar com culturas alimentares e a plantação de eucalipto é feita num sistema agroflorestal junto com outras árvores nativas que servem como energia para manter as caldeiras das microdestilarias funcionando; são testadas diversas espécies de cana para evitar a erosão genética e perda da diversidade biológica; não são usadas sementes transgeneticamente modificadas, mas sim, sementes crioulas; os camponeses continuam residindo em seu local de produção, assim, a reprodução material e cultural camponesa continua se fazendo em seus territórios, evitando a desterritorilaização e a perda da diversidade cultural; o produto não é a vendido para o mercado capitalista, assim, evita-se a subordinação de sua renda ao capital agroindustrial e contraria a lógica da produção de commodities, transformando em Soberania Energética; não se produz apenas álcool, mas também, cachaça e rapadura, no mesmo sistema de organização.

Desse modo, "a produção de alimentos e culturas para produção de agrocombustíveis, de forma agroecológica, também é uma experiência em desenvolvimento pelo Movimento dos Pequenos Agricultores [...]" (Fernandes, Welch e Gonçalves, 2010, p. 10). Para nomear essa experiência, o MPA criou um termo: "ALIMERGIA". A partir desse paradigma, o movimento tem como principal meta: a produção de Alimentos e Energia, com Respeito ao Meio Ambiente, no interior do modo de produção camponês, entendendo o mesmo como uma célula, parte de um território, que tem relação com o todo (Leal, 2007 apud Camacho, Cubas e Gonçalves, 2011). Assim, a Cooperativa Mista de Produção, Industrialização e Comercialização de Biocombustíveis do Brasil Ltda. (Cooperbio), vinculada ao MPA, constitui o Sistema Camponês de Produção. Este modelo: "[...] apesar dos frágeis resultados econômicos e da semelhança da produção de agrocombustivel a um pequeno agronegócio, o SCP é um ordenamento produtivo de alimentos e agroenergia erguido de baixo para cima: a partir [...] das unidades camponesas de produção". (Fabrini, 2011, p. 102). 
Os biocombustíveis podem ser produzidos em modelos alternativos que integrem a produção de alimentos, energias renováveis e serviços ambientais em sistema descentralizados organizados pela agricultura camponesa. Este modo de produção está focado na autonomia energética em níveis de unidade de produção, comunitária, territorial, e interterritorial de forma e articular-se com os sistemas de produção de alimentos, serviços ambientais e com a ocupação popular do território, garantindo suporte econômico-ecológico sustentável a produção e reprodução de sistemas camponesas e sua relação com as cidades, integrando estes dois sistemas em um contínuo de trocas materiais, energéticos e econômicas. (Cavalett, Leal e Rydgerg, 2010 apud Fabrini, 2011, p. 103).

A partir da Figura 3 podemos visualizar uma comparação que mostra as diferenças entre as formas de produção do agronegócio e as formas de produção camponesa que configuram a estrutura da Cooperbio (Cooperativa de Produção de Bicombustíveis), cooperativa engendrada pelo Movimento dos Pequenos Agricultores. A forma de organização da Cooperbio, que é possível de ser visualizada na Fotografia 1, é formada por: Agrofloresta (interação floresta e culturas da alimergia), Floresta Energética (cultivo diversificado de culturas necessárias para a produção de energia que movimenta as micro-destilarias), Micro-Destilarias e Produção agrícola diversificada (policultura). Esta organização forma os agroecossitemas camponeses e a lógica camponesa de produção de alimentos e energia de forma integrada. A Cooperbio é responsável apenas pela produção e a CPC (Cooperativa de Produção Camponesa) realiza a parte de distribuição/mercado (Camacho; Cubas; Gonçalves, 2011).

Figura 3. Comparação entre os modelos de Produção do Agronegócio e a Produção Camponesa de agrocombustíveis.

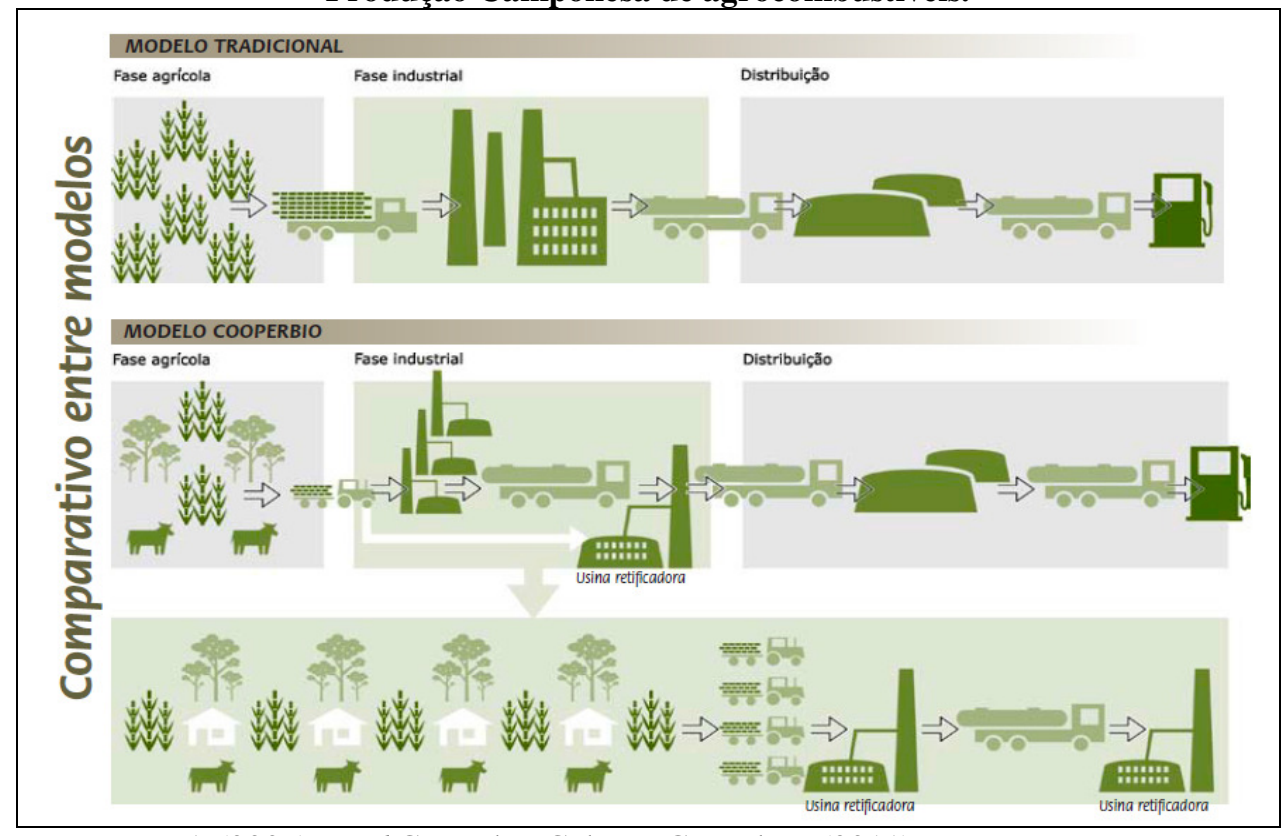

Fonte: MPA (2007) apud Camacho, Cubas e Gonçalves (2011). 


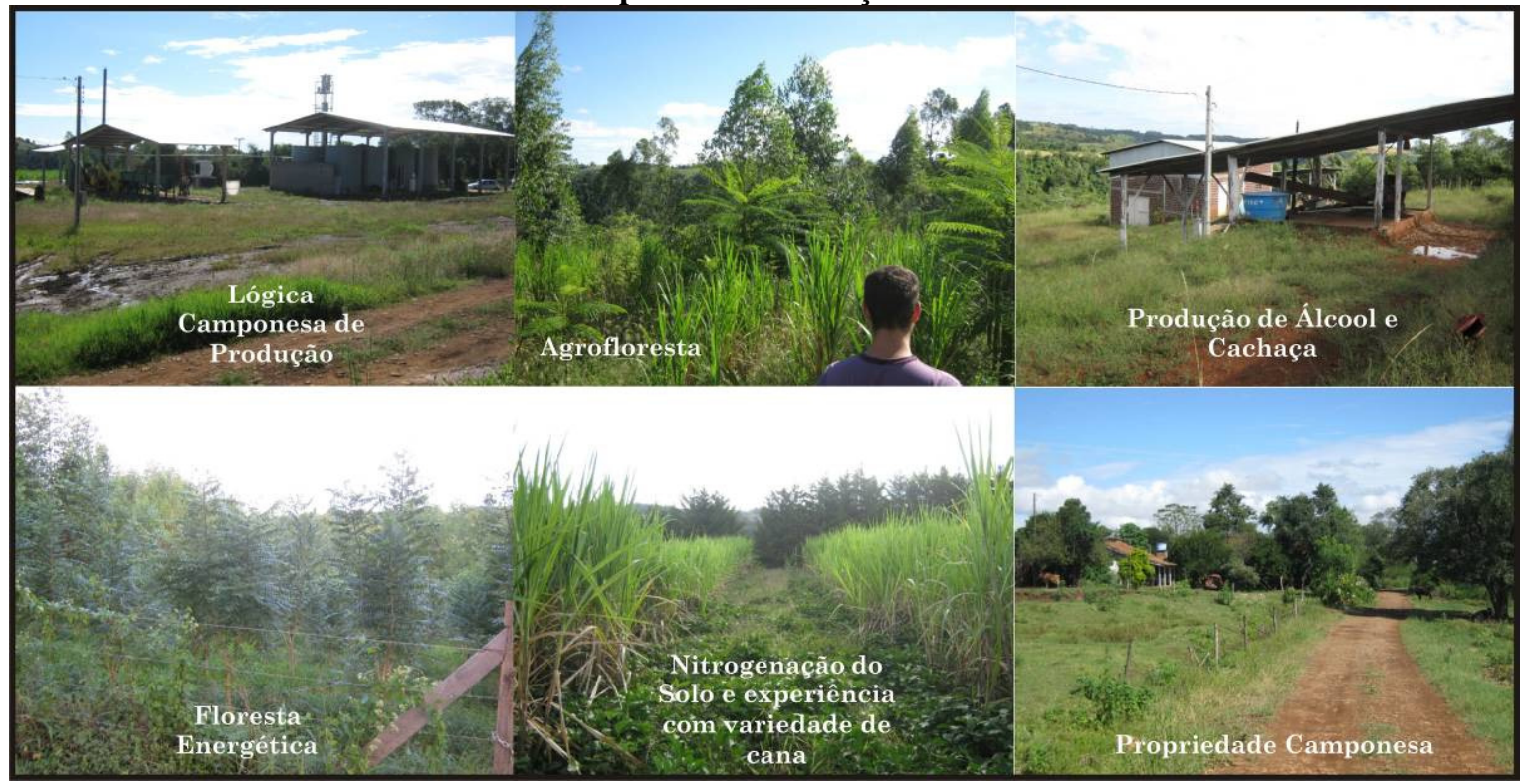

Fonte: Camacho, Cubas e Gonçalves (2011)

Estas micro-destilarias podem trabalhar com a produção diversificada e a partir de um formato de manejo, cujo ciclo constituído neste processo, tende a degradar de maneira bem menos impactante a natureza, pois consegue uma alta taxa de renovabilidade. A produção pode ser voltada para a cana-de-açúcar, batata doce, mandioca e sorgo sacarino. Essas micro-destilarias ainda são capazes de produzir açúcar mascavo, melado, rapadura, cachaça, ração animal, adubo orgânico e álcool. Trabalhando também com sistema de moenda móvel ou fixa. Este modelo tem como principais contribuições: o manejo sustentável do solo, a diversificação da matriz produtiva regional, o manejo de recursos naturais e uma agroindustrialização a favor da reprodução do território/territorialidade camponesa (Leal, 2007 apud Camacho, Cubas e Gonçalves, 2011).

\section{CONSIDERAÇÕES FINAIS}

Demonstramos em nossas reflexões que o agronegócio não é um modelo viável para a nossa sociedade. Nesse sentido, devemos nos propor a pensar em que tipo de sociedade queremos. $\mathrm{O}$ uso da terra é uma questão que diz respeito a toda a sociedade. Está provado a partir da pesquisas de Oliveira (2003) que quem produz alimentos para a população brasileira é a pequena propriedade, e não o latifúndio do agronegócio, pois este produz para as nações desenvolvidas consumirem soja, suco laranja, etanol, etc. Dessa maneira, buscamos combater a ideologia neoliberal que prega a importância que tem o agronegócio para a população brasileira, por aumentar o PIB nacional, por meio de suas commodities, por gerar empregos, produzir alimentos etc. Deturpando assim, a essência dos fatos, ou seja, sua face bárbara, excludente e destruidora.

Os principais veículos de comunicação de massa manipulam as informações em detrimento dos movimentos sociais camponeses e indígenas, que tentam construir um outro modelo de uso da terra no campo, que não é o modelo do agronegócio. É notória a campanha que estes veículos de comunicação vêm fazendo a fim de criminalizar os movimentos sociais, sempre enfatizando o 
discurso ideológico neoliberal de que esses movimentos colocam em risco a democracia e o direito a propriedade privada.

Por isso, é necessário reiterar que o agronegócio tem se constituído, como as plantations no Brasil colonial, num conjunto predador da sociobiodiversidade, tendo como características principais: a monocultura, o latifúndio, a exploração intensa do trabalho e a exportação. Pois, além de expulsar os camponeses e causar o êxodo rural, principal responsável pelos problemas urbanos, seus agroecossistemas simplificados da monocultura exigem o uso de agroquímicos que degradam o meio ambiente desestruturando o equilíbrio ambiental. Logo, a solução para o problema está no incentivo à resistência, reprodução e recriação da agricultura dos povos do campo, para assim, garantir a reprodução de nossa diversidade biológica e sociocultural.

\section{REFERÊNCIA BIBLIOGRÁFICA}

ALMEIDA, R. A. de. (Re) criação do campesinato, identidade e distinção: a luta pela terra e o habitus de classe. São Paulo: UNESP, 2006.

ALMEIDA, R. A. de (Org.). Pequeno glossário da questão agrária. Três Lagoas, 2004. (Mimeografado).

ALMEIDA, R. A. de e PAULINO, E. T. Fundamentos teóricos para o entendimento da questão agrária: breves considerações. Revista Geografia, Londrina, v.9, n.2, p. 113-127, jul./dez.2000.

BALDUÍNO, D. T. O campo no século XXI: território de vida de luta e de construção da justiça social. In: OLIVEIRA, A. U. de e MARQUES, M. I. M. (Org.). O campo no século XXI: território de vida, de luta e de construção da justiça social. São Paulo: Casa amarela; Paz e Terra, 2004.

BETTO, F. Necrocombustíveis. Disponível em: <http://amaivos.uol.com.br/>. Acesso em out. 2007.

CAMACHO, R. S. O ensino da geografia e a questão agrária nas séries iniciais do ensino fundamental. 2008. 462 p. Dissertação (Mestrado em Geografia) - Universidade Federal de Mato Grosso do Sul, Aquidauana, 2008.

CAMACHO, R. S., CUBAS, T. e GONÇALVES, E. Agrocombustíveis, soberania alimentar e políticas públicas: as disputas territoriais entre o agronegócio e o campesinato. Boletim DATALUTA, Presidente Prudente: Unesp/NERA, v.1, p.1 - 29, 2011.

CASAldÁligA, D. P. In: SILVA, E. L. Terra. Revista Fórum: outro mundo em debate, São Paulo: Publicher Brasil, n. 25, p. 8-11, abr. 2005.

ENGELS, F. Sobre o papel do trabalho na transformação do macaco em homem. In: Textos. São Paulo: [s.n], 1977. (Mimeografado).

FABRINI, J. E. Território, classe e movimento sociais no campo. Revista da Anpege: Associação Nacional de Pesquisa e Pós-graduação em Geografia, v. 7, n. 7, p. 97-112, jan./jul. 2011. 
FAO. Organización de las Naciones Unidas para la Agricultura y la Alimentación Viale delle Terme di Caracalla. El estado mundial de la agricultura y la alimentación: biocombustibles perspectivas, riesgos y oportunidades. Roma: FAO, 2008.

FERNANDES, B. M. Agricultura de mercado, campesinato e agronegócio da laranja nos EUA e Brasil. In: PAULINO, E. T. e FABRINI, J. E. (Orgs.). Campesinato e territórios em disputa. São Paulo: Expressão Popular, 2008a. p. 161-186. (Geografia em Movimento).

FERNANDES, B. M. Entrando nos territórios do Território. In: PAULINO, E. T. e FABRINI, J. E. (Org.). Campesinato e territórios em disputa. São Paulo: Expressão Popular, 2008b. p. 273 301. (Geografia em Movimento).

FERNANDES, B. M. Questão agrária: conflitualidade e desenvolvimento territorial. Disponível em: <http://www4.fct.unesp.br/nera/arti.php>. Acesso em: 20 mai. 2009.

FERNANDES, B. M. e MOLINA, M. C. O campo da educação do campo. In: MOLINA, M. C. e JESUS, S. M. S. A. de (Org.). Por uma educação do campo: contribuições para a construção de um projeto de educação do campo. Brasília: Articulação Nacional "Por Uma Educação do Campo", 2004. p. 53-91. (Por Uma Educação do Campo, 5).

FERNANDES, B. M., WELCH, C. A. e GONÇALVES, E. C. Políticas de agrocombustíveis no Brasil: paradigmas e disputa territorial. [S.1.: s.n.], 2010.

PORTO-GONÇALVES, C. W. Geografia da riqueza, fome e meio ambiente: pequena contribuição crítica ao atual modelo agrário/agrícola de uso dos recursos naturais. In: OLIVEIRA, A. U. de e MARQUES, M. I. M. (org.). O campo no século XXI: território de vida, de luta e de construção da justiça social. São Paulo: Casa amarela; Paz e Terra, 2004. p. 27-64.

GORENDER, J. Gênese e desenvolvimento do capitalismo do capitalismo no campo brasileiro. In: STEDILE, J. P. (Org.) A questão agrária hoje. 2. ed. Porto Alegre: UFRGS, 2002.

LEAL, M. Cooperbio. Uma Cooperativa do Movimento dos Pequenos Agricultores. In: ORTIZ, L. S. Construindo a Soberania Energética e Alimentar. Porto Alegre: Núcleo Amigos da Terra/Brasil, 2007.

MST. VIA CAMPESINA BRASIL. Agrotóxico mata: campanha permanente contra os agrotóxicos e pela vida. [S.L, s.n], 2011.

OLIVEIRA, A. U. de. A geografia agrária e as transformações territoriais recentes no campo brasileiro. In: CARLOS, Ana F. A. (Org.). Novos caminhos da geografia. São Paulo: Contexto, 1999. p. 63-137.

OLIVEIRA, A. U. de. As relações de produção na agricultura sob o capitalismo. In: Modo capitalista de produção e agricultura. São Paulo: Ática, 1986. p. 61-78.

OLIVEIRA, A. U. de. Barbárie e modernidade: as transformações no campo e o agronegócio no Brasil. Revista Terra Livre, São Paulo: AGB, ano 19, v. 2, n. 21, p. 113-156, jul./dez., 2003.

OLIVEIRA, A. U. de. Geografia agrária: perspectivas no início do século XXI. In: OLIVEIRA, A. U. de e MARQUES, M. I. M. (Org.). O campo no século XXI: território de vida, de luta e de construção da justiça social. São Paulo: Casa amarela; Paz e Terra, 2004. p.27-64. 
PROGRAMA NACIONAL DE PRODUÇÃO E USO DE BIODIESEL (PNPB). Disponível em: $<$ http://www.biodiesel.gov.br/programa.html 1>. Acesso em: 13 set. 2009.

ROMEIRO, A. R. Reforma agrária e distribuição de renda. In: STEDILE, J. P. (Org.). A questão agrária hoje. 2. ed. Porto Alegre: UFRGS, 2002.

SANTOS, Milton. A transição em marcha. In: Janeiro: Record, 2001. p. 141-174. . Por uma outra globalização. 6. ed. Rio de

SOUZA, H. O. de. Entrelinhas - a mídia como ela é: inversão de relevância. Revista Caros Amigos, São Paulo: Casa Amarela, ano 10, n.109, p. 9, abr. 2006.

STEDILE, J. P. et al. Manifesto das Américas em defesa da natureza e da diversidade biológica e cultural. Revista Caros Amigos, São Paulo: Casa Amarela, ano 10, n. 112, p.40, jul. 2006b.

STEDILE, J. P. A questão agrária e o socialismo. In: STEDILE, João Pedro (org.) A questão agrária hoje. 2. ed. Porto Alegre: UFRGS, 2002.

STEDILE, J. P. A sociedade deve decidir o modelo agrícola para o país. Revista Caros Amigos, São Paulo: Casa Amarela, ano 10, n.109, p. 17, abr. 2006a.

STEDILE, J. P. O aumento dos preços dos alimentos e o agronegócio. Revista Caros Amigos, São Paulo: Casa Amarela, ano 14, n. 167, p. 11, fev. 2011.

STEDILE, J. P. Por que o preço dos alimentos disparou? Revista Caros Amigos, São Paulo: Casa Amarela, ano12, n.135, p.37, jun. 2008.

STEDILE, J. P. Questão agrária no Brasil. São Paulo: Atual, 1998.

STEDILE, J. P. Soberania alimentar, o que é isso? Revista Caros Amigos, São Paulo: Casa Amarela, ano 10, n. 120, p. 42, mar. 2007.

VASCONCELOS, G. F. Latifúndios no Brasil, o objetivo de Bush. Revista Caros Amigos, São Paulo: Casa Amarela, ano 10, n. 120, p.34, mar. 2007.

VIA CAMPESINA. Nota oficial da via campesina: pequenos produtores esfriam o planeta. Disponível em: <www.mst.org.br>. Acesso em: 14 nov. 2007.

VIDAL, J. W. B. Sem competir com o petróleo. Revista Caros Amigos, São Paulo: Casa Amarela, ano 10, n. 120, p. 36, mar. 2007.

(C) Copyright Rodrigo Simão Camacho, 2012.

(c) Copyright GeoGraphos. Revista Digital para Estudiantes de Geografía y Ciencias Sociales, 2012. 


\section{Ge Graphos}

REVISTA DIGITAL

PARA ESTUDIANTES DE GEOGRAFÍAY CIENCIAS SOCIALES

ISSN: $2173-1276$ 